\title{
6 Rom 12.1-2 as an exhortation to genuine humanness
}

In this chapter, we propose a novel explanation of Paul's reason language in Rom 12.1 and show how it works exegetically in Rom 12.1-2. The key to our solution lies in the recognition of the relevance of Epictetus 1.16 as a parallel to

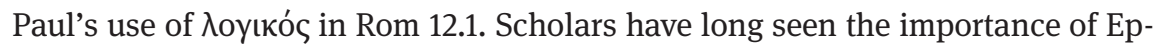
ictetus 1.16 as a parallel to Rom 12.1. But because they have not usually read Epictetus 1.16 as being about genuine humanness and the human vocation, they have not determined the pertinence of the parallel in the way we propose here. In Epictetus 1.16, 入oyı́ó specifies the distinct human capacity on which a human vocation within the cosmos is based. It is in this sense, we argue, that Paul uses the language of $\lambda$ oyıkós, because he wants to make a claim about genuine humanness and the human vocation.

The goal of this chapter is to detail this claim and show how it works exegetically in Rom 12.1. In the next chapter we will show the implications this reading has for the function of Rom 12.1-2 as a transition between Rom 1-11 and Rom 12-16, and in particular as an overture to Rom 12-15.

Before we begin our argument, it will be useful to cite the text of Rom 12.1-2 and to indicate how we shall refer to it:

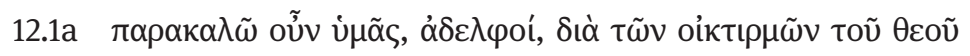

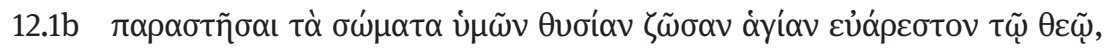

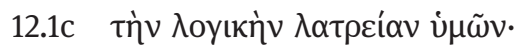

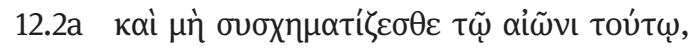

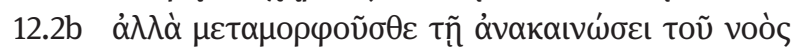

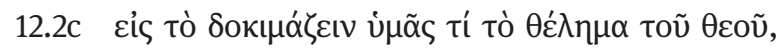

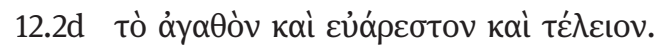

The steps required for our argument in this chapter are the following:

First, we will show, based on an analysis of the syntax of Rom 12.1, that Rom $12.1 \mathrm{c}$ is a comment upon Rom $12.1 \mathrm{~b}$, and that Rom $12.1 \mathrm{~b}$ is a description of an action to which Rom 12.1a exhorts; this is obvious but has important consequences (section 6.1).

Second, we will show that Rom 12.1b draws on the rapíotavat language of Rom 6 to create a cultic metaphor which is used to describe the action to

Ә OpenAccess. (c) 2021 Simon Dürr, published by De Gruyter. (cc) BY-NC-ND This work is licensed under the Creative Commons Attribution-NonCommercial-NoDerivatives 4.0 International License. 
which Paul exhorts as a sign production ${ }^{1}$ in the sense he has explained in Rom 6 (section 6.2).

Third, we will show that Rom 12.1c ( fect of saying "this is your genuinely human vocation" (section 6.3).

Once we have done this, we further consider how Rom 12.2 coheres with our interpretation of Rom 12.1 (section 6.4).

\subsection{The syntax of Rom 12.1 as criterion}

In this section, we show that the syntactic structure of Rom 12.1 falls into three principal parts: ${ }^{2}$ Rom 12.1a marks Rom 12.1 as an act of exhortation to a certain action; Rom 12.1b is a description of that action; Rom 12.1c is a comment upon that description of an action. We shall then point to a consequence for the interpretation that follows from this simple observation. It provides a strong argu-

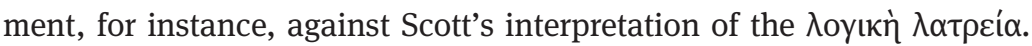

The analysis of the structure of Rom 12.1 is based on the following points. The infinitive $\pi \alpha \rho \alpha \sigma \tau \tilde{\eta} \sigma \alpha \mathrm{s}$ is directly dependent upon the verb $\pi \alpha \rho \alpha \kappa \alpha \lambda \tilde{\omega}$. $\pi \alpha \rho \alpha-$ $\kappa \alpha \lambda \varepsilon \tilde{v} v$ can be used to express a range of meanings but, with an infinitive depending on it, it is clear that its meaning must be a summons to an action, here an encouragement, an invitation or an exhortation. ${ }^{3}$ As we have seen in Epictetus 1.16.21, where Epictetus uses $\pi \alpha \rho \alpha \kappa \alpha \lambda \tilde{\omega}$ as well, it is a suitable verb to be

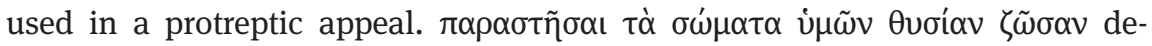

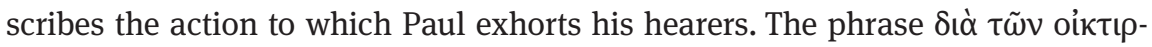

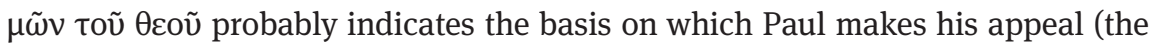
mercy of God has brought Paul to the position he is currently in to make such an exhortation). ${ }^{4}$

As most scholars recognise, Rom 12.1c is in apposition to Rom 12.1b as a whole (not to $\theta v \sigma i ́ \alpha v$ ). ${ }^{5}$ As this will be important later, we shall briefly expand

1 We repeat here the definition of "sign production" which we use, in Paul, for "actions performed in such a way as to signify, embody and express the truths and meanings of the Christ event" (see section 1.4).

2 We are indebted to the analysis of Reichert 2001, 228-229.

3 Cf. LSJ, s.v.

4 So Wolter 2014, 250. Others connect the "mercies" with Paul's exposition in the preceding chapters and make it the "foundation" of the act of $\pi \alpha \rho \alpha \sigma \tau \tilde{\eta} \sigma \alpha \mathrm{I}$ (so for instance Barclay 2015, 508). Further options are discussed by Reichert 2001, 229 n. 31.

5 So e.g. Cranfield 1979, 601; Reichert 2001, 229 n. 33. Against, for instance, Seidensticker 1954 who sees it as in apposition to $\theta v \sigma i ́ \alpha$ (interpreted as referring to a ritual act rather than as that which is offered in such an act). 
upon this point. The most recent English grammar of ancient Greek defines an apposition as follows: "Apposition is the placement of two words or word groups parallel to each other without any coordinating particle ..., with one, the 'appositive' defining or modifying the other." ${ }^{\prime}$ Rom 12.1c, as an appositive, is in the accusative, just as would be expected given the assumption that it modifies an entire clause. $^{7}$

The consequence of this analysis is that Rom $12.1 \mathrm{~b}$ is the topic, upon which the appositive 12.1c makes a comment, and not the other way round. ${ }^{8}$ And given that Rom 12.1a marks an exhortation, it follows, that the comment which is made upon the action to which Paul exhorts should also contribute to the exhortation. Indeed, Rom 12.1-2 is a well-structured passage which appears at an important transitional moment in the letter, so it would be highly unlikely for Paul to use Rom 12.1c for a digression which does not serve the communicative purpose of exhortation. This should lead us to expect that Rom 12.1c offers a motivation for the action to which Paul exhorts, or confers a positive valuation upon it. This criterion - that Rom 12.1c should help motivate Rom 12.1b - is not met by Scott's interpretation, for instance, in which Rom 12.1c merely describes the action Rom $12.1 \mathrm{~b}$ as involving processes of reasoning. ${ }^{9}$ This criterion also makes those interpretations less likely which see Paul using Rom 12.1c mainly to create a polemical contrast with the cults of Rome or Jewish temple worship.

This criterion should be met for any interpretation of 12.1b and Rom 12.1c. With this we turn to the interpretation of Rom 12.1b.

6 CGCG, 26.24.

7 Cf. CGCG, 30.19: "When an appositive is added to an entire sentence or clause, it normally stands in the accusative."

8 As noted by Reichert 2001, Wolter 2019. This point is missed, for example, by Thorsteinsson 2010, 138: "Paul here [i.e. Rom 12.1, SD] defines the audience's 'reasonable worship' ... in terms of an 'offering' their bodies as a 'living sacrifice' ... to God." Paul is not saying: "Let me now tell you what your reasonable worship is: it is offering your bodies as living sacrifice." He is encouraging an action, on which he then makes a comment; he is not establishing a topic, on which he then makes a point.

9 Rom 12.1c needs to be something that expresses value and something eminently positive in

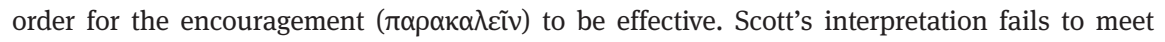
this criterion, because making a statement about the fact that the believers' ethical decisions involve "reasoned argument" makes little sense as something that supports Paul in his exhortation or appeal. 


\subsection{Present your bodies as a living sacrifice: The interpretation of Rom 12.1b}

In this section, we seek to show that the action to which Paul exhorts in Rom $12.1 \mathrm{~b}$ is a sign production which uses the body to display the understanding of God that has been revealed in the death and resurrection of Christ. Because this understanding involves the belief that in Christ a new creation has been inaugurated, we might also refer to this as producing signs of the new creation. Similarly, because these signs are supposed to articulate and embody what

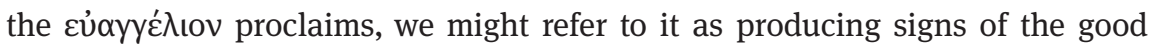
news.

Thus, our reading of Rom $12.1 \mathrm{~b}$ involves recognising a distinction between the identification of the referent of the action and the description of that action. The referent of the action is rather broad, namely the entire way of life in the communities of Christ-followers, such as it conforms to Paul's ideal, which he presents in Rom 12.3-15.13 and to which Rom 12.1-2 functions as the overture. But Paul's way of describing the action - by means of a cultic metaphor involving $\pi \alpha \rho i ́ \sigma \tau \alpha v \alpha$ l language - does not only refer to an action, but also says something about this action. We propose that what this description amounts to is that these actions function as signs of new creation, of the good news, of genuine humanness. That is, these actions, whether "ethical" acts or acts of worship (in the narrow sense), have a "missional" ${ }^{10}$ function: they are signs which communicate something about who God is and what he has done in the Christ event.

This reading rests squarely on the links between the $\pi \alpha \rho$ í $\sigma \alpha v \alpha$ l language in Rom 12.1 and in Rom 6. As we have shown (in section 5.3.2.2), Paul has deliberately crafted this language in Rom 6 to explain that the significance of the Christ event should find expression in the actions of the liberated body. That is, he uses it to explain that the actions of Christ-followers in the present should be signs of

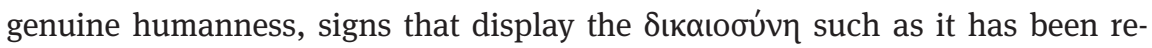
vealed in Christ. And this explanation is what Paul's language used in Rom $12.1 \mathrm{~b}$ recalls.

While Rom 6.13, 6.16, 6.19 used $\pi \alpha \rho i ́ \sigma \tau \alpha v \alpha ı$ language to construct a metaphor involving the domain of warfare or slavery, Rom 12.1 uses it to construct a cultic or sacrificial metaphor. ${ }^{11}$ But in both cases the body or members are to be employed in actions which involve an element of sign production: in Rom 6 this el-

10 On our use of "missional", see section 1.4.

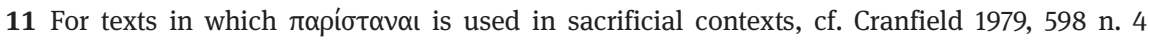
(though his conclusion from the evidence is unwarranted). 


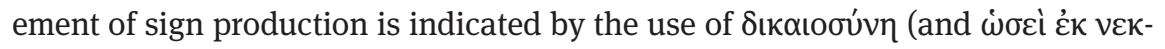
$\rho \tilde{\omega} \nu \zeta \tilde{\omega} \nu \tau \alpha \varsigma$ or $\left.\dot{\alpha} y \_\alpha \sigma \mu o ́ \varsigma\right)$; in Rom 12.1 the sign aspect is expressed by the use of the predicative complement $\theta v \sigma i \alpha v$ : the action of presenting your bodies as a (living) sacrifice.

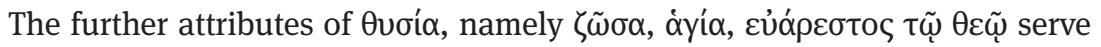
to underline this aspect and support our interpretation of Rom 6 and Rom 12.1b as explaining sign production. While the attribute $\zeta \tilde{\omega} \sigma \alpha$ does serve to distinguish the $\theta v \sigma i \alpha$ from one for which the victims are killed, it does not stretch the bold metaphor to suppose that it also points to the new "eschatological" life which has been given to Christ-followers (cf. Rom 6.4, 6.11, 6.13). The attribute öyıs in $12.1 \mathrm{~b}$ recalls the óyı $\alpha$ ouó in Rom 6.19, 6.22, which we have also explained

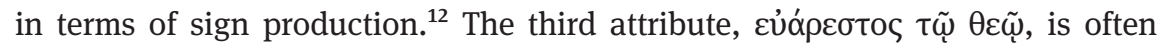
used for behaviour with which God is pleased, but is almost never used for sacrifices, so that at this point Paul's "sacrificial” metaphor is mixed with language used to describe the life which is characterised by the cultic metaphor. ${ }^{13}$ But in all three cases, these attributes point to the effect of the right action: it produces a sign in which something becomes "visible", both to other human beings and before God.

The point we need to stress, however, is that Paul's use of a cultic metaphor in Rom 12.1b does not by itself imply that he is speaking about the "true cult", or, to put it differently, that he is concerned, at this point in the letter, with contrasting the worshipping practices of Christ-followers in their gatherings with pagan sacrificial practices. Of course, Paul does think that the presence of the Spirit in Christ-followers amounts to something which far surpasses any supposed numinous presence at a pagan temple. But using a metaphor from the domain of cult does not necessarily mean that a speaker is thereby making a point about cult.

Rather, Paul is referring to the entirety of Christ-followers' existence, which includes worship and ethical action, in such a way as to emphasise its missional effect. That Paul is concerned with such a missional aspect in Rom 12.1 has been noted by Reichert, ${ }^{14}$ though she bases this observation on a doubtful interpreta-

12 This is further supported by Wolter's observation, with reference to texts such as Deut 7.6, that öyıৎ is used to mark how Israel's identity as elected people is expressed in their way of life $(2019,251)$.

13 Cf. Wolter 2019, 252 (noting a few exceptions).

14 Reichert 2001, 244: "Die leibliche Selbstübereignung der Adressaten and Gott [her paraphrase of Rom 12.1b, SD] ist als ein Geschehen begriffen, dem von sich aus Mitteilungskraft eignet." 


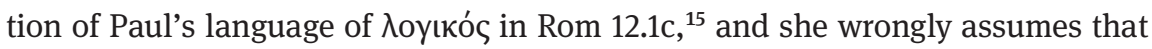
the missional aspect excludes action. ${ }^{16}$

It is especially tempting for interpretations that see $\lambda \alpha \tau \rho \varepsilon$ í $\alpha$ in Rom 12.1c as referring to "religion" to mistake the cultic language used to make a point in Rom 12.1b for the point itself. Having said that, it may very well be the case that Paul finds thinking about the purpose of human beings in terms of priestly service a very fruitful approach. And such resonances may even be implied by his use of cultic language. Nevertheless, it remains the case that the intratextual links to Rom 6 make it likely that what he is primarily speaking about in Rom 12.1b is the entirety of Christ-followers' existence as missional, as producing signs of the new reality which has been inaugurated in Christ's death and resurrection.

Thus, we conclude that the action to which Rom 12.1b exhorts is a sign production, which uses the body for actions that function as signs of the new reality which has been inaugurated in the messiah. Hence it refers both to a "messianic" existence and to its missional effect. It is upon this description of the action that Paul comments in Rom 12.1c, using the language of $\lambda$ oyıкós in a way we will now seek to explain.

\subsection{Rom 12.1c: "This is your truly human calling"}

In this section, we seek to show that Rom 12.1c has the effect of saying "this is your truly human vocation" as a comment upon the action to which Paul exhorts

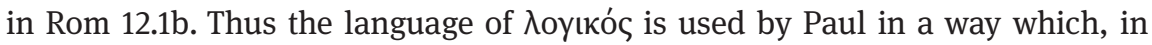
combination with $\lambda \alpha \tau \rho \varepsilon i ́ \alpha$, amounts to the concept of a "human vocation", in the sense of the Greco-Roman philosophical tradition we have investigated in chapters 3-4. If this interpretation is on target, Rom 12.1 could be paraphrased as: "I exhort you use your (liberated) bodies to produce signs (of the new crea-

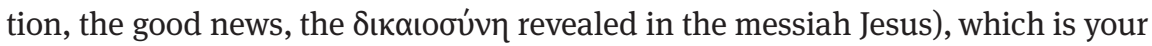
genuinely human vocation.” Thus Paul would be saying in Rom 12.1, by an allu-

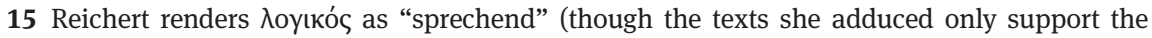

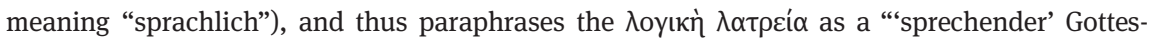
dienst, der sich Aussenstehenden gegenüber bemerkbar macht” (2001, 244). This sense would fit better with Rom 12.1b.

16 When she claims that Rom 12.1 is not about "ein intentional anzusteuerndes "Tatzeugnis"” but only about "die der Welt kommunikativ zugewandte Seite gemeindlicher Existenz" (2001, 245). 
sion to a philosophical tradition about human beings as $\theta v \eta \tau \dot{\alpha} \lambda$ oyık $\grave{\alpha} \zeta \tilde{\omega} \alpha,{ }^{17}$ that the vocation of Christ-followers is the genuinely human vocation.

To argue for this interpretation, the following steps are required: First, we need to show that $\lambda \alpha \tau \rho \varepsilon i ́ \alpha$ in Rom 12.1c is used to speak about a service to God as a vocation (section 6.3.1). Second, we have to establish the sense of $\lambda$ oyt-

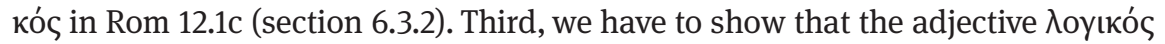
modifies the action noun $\lambda \alpha \tau \rho \varepsilon i ́ \alpha$ in such a way as to point to its subject (section 6.3.3).

\subsubsection{That $\lambda \alpha$ tpeía in Rom 12.1c is used to speak about a service to God as vocation}

In our first step, we show that $\lambda \alpha \tau \rho \varepsilon i ́ \alpha$ in Rom 12.1 is used to speak of service-toGod in such a way as to suggest the idea of a vocation (such as we have defined it). ${ }^{18} \lambda \alpha \tau \rho \varepsilon i ́ \alpha$ is an action noun which designates something which a group of people or an individual (the "subject") is doing either once or several times or habitually in fulfilment of a charge which the subject understands to have been laid upon it by God (or a god ${ }^{19}$ ). ${ }^{20}$ Many of the actions in view could be cultic in the proper sense: an offering at a temple performed by a priest, or an offering brought by someone to a temple and a priest, or an act of "worship" (prayer, vows etc.) by the subject performed in a designated, often cultic, setting. Thus, $\lambda \alpha \tau \rho \varepsilon i ́ \alpha$ is often translated as "worship" (in a narrow sense). ${ }^{21}$ But it

17 The fact that they are still "mortal" is not in tension with the "living sacrifice"; cf. our discussion in section 5.3.1.

18 Cf. section 1.4.

19 We will simply speak in the following of God, even where we could add "a god" or "a deity" to refer to the broader cultural context.

20 GE, s.v., distinguishes the following senses: first, the "condition of a servant, servitude, slavery" and figuratively, the "tasks or duties of life". Second, "service rendered to the gods, veneration, cult", where it is noted that the construction is usually with a genitive indicating the deity ( $\theta \varepsilon \circ \tilde{v}$ or $\theta \varepsilon \tilde{\omega} v)$. Note that for Rom 12.1, GE notes the sense "service rendered to God with one's own life" (though it paraphrases it, wrongly, in our view, with "spiritual service"). This could be taken in two senses: either in a merely ethical sense, in which a decently moral conduct is one's service to God, or, as we interpret it, in a vocational sense, that is, as a life oriented to a specific task, which to fulfil is what one's service to God with one's life is about, namely a missional existence that produces signs which proclaim the good news and the inauguration of new creation. 21 Cf. Cranfield 1958, 387 for an example of distinguishing three different senses of "worship" in English: "(i) to denote a particular element of what is generally referred to as worship, namely, adoration; (ii) to denote generally the public worship of the religious community gathered together and also the private religious exercises of the family and the individual; and (iii), in 
could also be used to refer to actions performed in obedience to God or understood to conform to the "will" of God which are not in the proper sense cultic but are simply seen as right and demanded by God. This could include ethical behaviour broadly (virtue) or be more specially understood as the task in life of a subject. But it is hard to distinguish these referents (we mean properly cultic or more broadly ethical acts) sharply: first, because the right kind of relation to the divine as an ethical act includes the proper cultic actions, however transactional or not they might have been understood or felt to be; and second, because the language and valuations associated with the cultic practices in the narrow sense can easily be transferred to non-cultic actions, such that ethical actions become described in language which properly would belong to the cultic domain. This widens the meaning of the language and casts these actions as similarly relating their subject to the divine as the cult proper would be understood to be doing. Hence $\lambda \alpha-$ $\tau \rho \varepsilon i ́ \alpha$ can also be used to refer to some charge which is more comprehensive in terms of how much of the life of its subject it demands. When someone sees her task in life as a $\lambda \alpha \tau \rho \varepsilon i ́ \alpha$ to God, then she figures the sum of her actions, ranging over non-cultic ones in the proper sense and cultic ones in the proper sense, as a service to God, and sees it as in some respect similar to those cultic actions in the narrow sense. Understood in this way, $\lambda \alpha \tau \rho \varepsilon i ́ \alpha$ becomes a way of speaking about a vocation: something which God demands from a subject, a task which needs to be discharged regularly or as an overall project to be achieved, and which constitutes a goal or end for this subject, to which other actions are subservient. ${ }^{22}$

\subsubsection{The example of Socrates in Plato's Apology}

A famous example in which $\lambda \alpha \tau \rho \varepsilon i$ is ised for such a vocation can be found in Plato's account of Socrates' speech at his trial. Socrates describes his own exami-

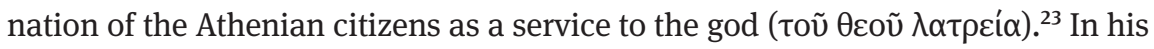
case, the god in question is Apollo, who answered to Chaerephon's request at the

a still wider sense, to denote the whole life of the community or of the individual viewed as service of God."

22 Cf. the texts in which the end is defined as that to which all other things refer, e.g. in Cicero, Fin. 1.29.11-14 (extremum et ultimum bonorum, quod omnium philosophorum sententia tale debet esse, ut ad id omnia referri oporteat, ipsum autem nusquam), cf. also 1.42.5-9, 3.21 and frequently; in Aristotle, cf. e.g. EN 1101b 29-31.

23 Plato, Apol. 20d-23c; DL 2.37. Epictetus would also have been aware of this (Long 2002, 55).

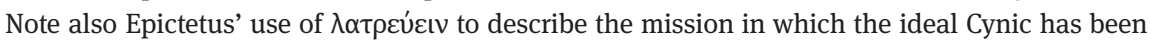

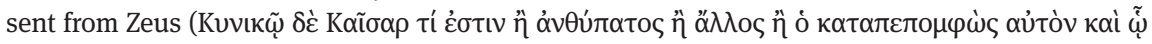

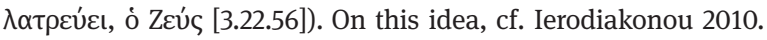


oracle of Delphi whether there is anyone wiser than Socrates with "no", which lead Socrates on a mission to refute that statement by finding someone wiser. This was the beginning of his examination of the citizens of Athens with bothersome questions about definitions of virtue and refutations of only apparent knowledge. ${ }^{24}$ Thus, the action referred to by a $\lambda \alpha \tau \rho \varepsilon i \alpha$ is in itself not cultic (talking to people in the market square). Rather, it is something that has occupied Socrates (as presented in the literary sources) for a good deal of his life, and it is something which seems so intensely important to Socrates that he would rather die than end this activity and shut up. It is something that he understood to be the task with which he was charged by the god. The total life of Socrates was devoted to his mission, and this includes acts that are cultic proper, such as offerings. ${ }^{25}$ However, at its core, it includes actions that are perhaps ethical but, more than that, serve an end to which he feels "called" and from which not even the threat of death would have him shrink back.

This example clearly demonstrates that $\lambda \alpha \tau \rho \varepsilon i ́ \alpha$ could be used to refer to a vocation, in this case of a particular human being. When combined with a word that can be used to speak about what makes humans distinct, in a context where capacity is assumed to be an indicator for proper function, and the role of

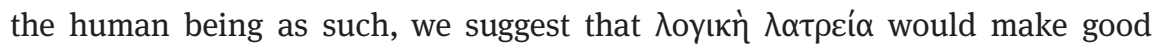
sense on the grounds of language use and of the relevant cultural knowledge as a way of speaking of a service to God which is appropriate for human beings as such, as the beings that they are assumed to be (in a broadly shared ancient view), namely those beings capable of $\lambda$ oyós, reason and speech, that is, as the 入оуıкоí they are.

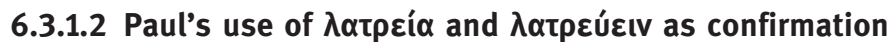

This reading is supported by the use of $\lambda \alpha \tau \rho \varepsilon v ́ \varepsilon เ v$ and $\lambda \alpha \tau \rho \varepsilon i ́ \alpha$ in Romans and in

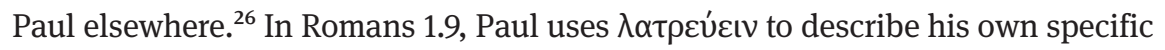

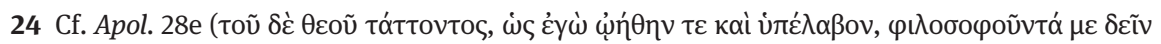

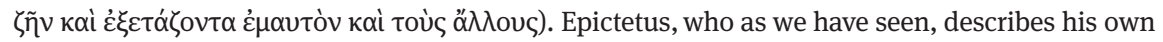

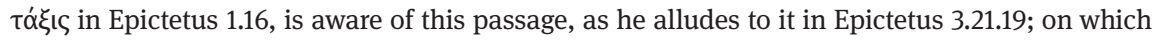
cf. Long 2002, 55.

25 Which Xenophon in his Memorabilia is at pains to show Socrates scrupulously observed. Cf. also the cock owed to Asclepius in the Phaedo (118a).

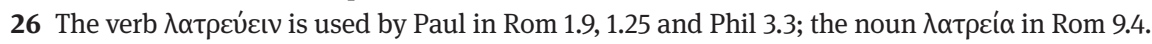
Betz 1991 argues that in Romans Paul attempts "to define his version of the gospel message as

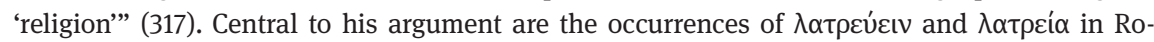

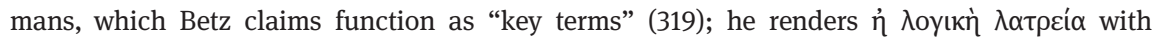
"the reasonable religion". Betz is basically right to emphasise that $\lambda \alpha \tau \rho \varepsilon i ́ \alpha$ is a "comprehensive 
activity and service to God. ${ }^{27}$ We have argued that Paul understands his own ministry as an apostle to be a paradigm for the service to which all Christ-followers are called. His might be a particularly intense form of that calling - but that merely shows more clearly in his case what would or should be true of others too (albeit perhaps in less intense form). This point is further supported by the consideration that Paul writes to the Romans in order to win them for a future collaboration, and this would work best if they lived with a similar sense of their

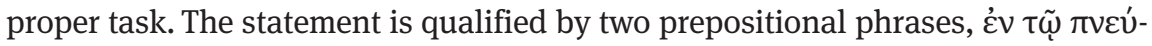

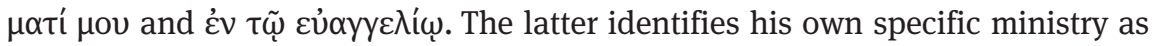
being about the good news of God's son. The good news (Rom 1.2-4) is part of Paul's stated vocational self-understanding (Rom 1.1); Paul's thesis statement describes what the good news does (Rom 1.16-17) and much of Romans is in fact a discussion of his understanding of the good news and how it relates both to himself and to the Romans. It is clear that Paul has a strong personal sense of a vocation. Our reading proposes that he also has a high sense of the vocation of the

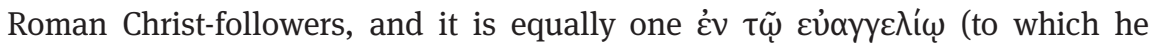
wants to encourage them with his overall letter). ${ }^{28}$ In fact, when he speaks of $\lambda о y ı$ ஸे $\lambda \alpha \tau \rho \varepsilon i ́ \alpha$ in Rom 12.1, it is this service which he has in mind. ${ }^{29}$ It is not en-

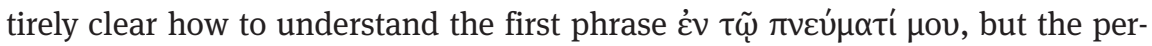
sonal pronoun $\mu \mathrm{ov}$ makes it certain that the reference is to the human spirit and not to the holy Spirit. Nevertheless one should not draw a hasty analogy between

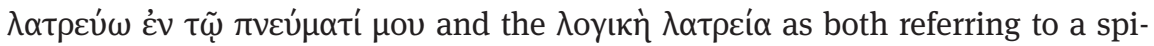

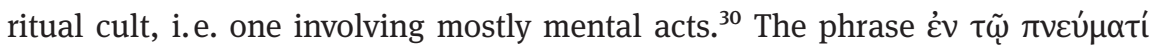
$\mu \mathrm{ou}$ probably simply expresses the intensity of his commitment. Paul would be saying: I am committed to this service with all of my being. ${ }^{31}$ Indeed, such

concept comprising ritual worship and ethics" (320), but he completely misses the dimension of a task in life, even as he stretches the meaning of terms in statements such as, regarding Rom 1.9, Paul's "worship is also identical with the preaching of the gospel" (321). Cf. the critical remarks of Reichert 2001, 245 n. 102.

27 God is explicitly mentioned (ó $\theta \varepsilon o ́ c, \tilde{\tilde{\omega}} \lambda \alpha \tau \rho \varepsilon v ́ \omega)$.

28 Paul's sense of how his own vocation differs from that of other Christ-followers comes through clearly in Rom 15.16.

29 Though at in Rom 12.1 this comes through via the comment that $12.1 \mathrm{c}$ makes upon $12.1 \mathrm{~b}$ (which describes, as we have argued, the sign production of the good news).

30 This is clear from the fact that the service also has to do with the good news, which requires communication to others and is outward focused. Differently, Betz 1991, 320 n. 13.

31 This case is thus different from Phil 3.3 where Paul characterises the Christ-followers" "we"

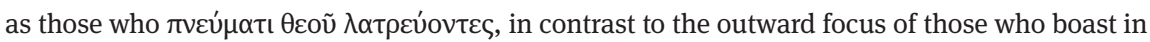
the flesh. (The latter contrast may be similar to that used in Rom 2.29.) Cf. Philo, Spec. 1.300

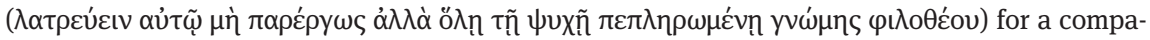


a reading fits with the total commitment to which Rom 12.1b encourages. Thus, the language of $\lambda \alpha \tau \rho \varepsilon v$ $\varepsilon v$ in Rom 1.9 fits very well with our interpretation of a service to God which is the task in life or vocation of its subject. ${ }^{32}$

In Rom 1.25, the language of $\lambda \alpha \tau \rho \varepsilon v$ cıv is used negatively to characterise a failure on the part of the humans described in Rom $1.18-32 .{ }^{33}$ It is semantically parallel to $\sigma \varepsilon \beta \alpha \dot{\alpha} \varepsilon \sigma \theta \alpha \mathrm{l},{ }^{34}$ which seems at first to suggest that the sense might be more nearly worship (in the narrower sense) rather than service (in the more comprehensive sense). Also, the context of idolatry in Rom 1.23 seems to support this reading. On the other hand, it seems too specific to take actual nature worship as the topic of the verse. If Paul wants to characterise comprehensively the wrong behaviour of humans he could also synecdochically pick out one characteristic aspect of their behaviour, one which is perceived to have ramifications for all aspects of life, such as worship of the one God would have been for Jews. ${ }^{35}$ Thus, right worship ${ }^{36}$ can stand pars pro toto to express the overall orientation of a life. Further, given that life as a whole can sometimes be described as a service to God, the failure of such a life could easily be expressed as a false kind of

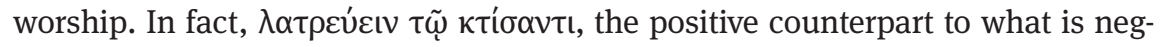

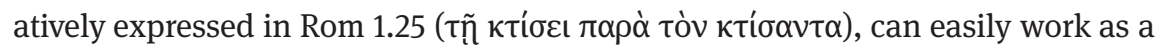
comprehensive formula for the human calling in a Jewish monotheistic perspec-

rable statement, in which the intensity of dedication is expressed in similar terms, although

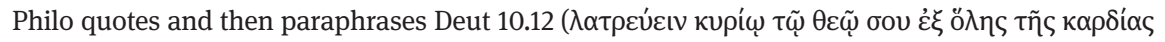

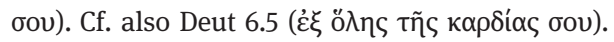

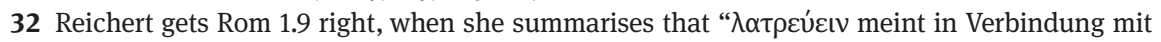

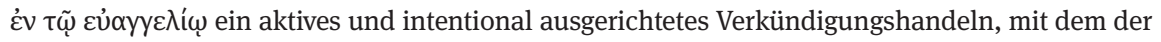
Verfasser seiner Bestimmung entspricht” (2001, 123), but she unhelpfully drives a wedge between Paul's Verkündigungshandeln and the $\lambda \alpha \tau \rho \varepsilon i ́ \alpha$ of the communities to which Paul writes, in which she sees "kein intentionales Verkündigungshandeln ..., sondern den kommunikativen Effekt der sich mit der Übereignung von Weltsegmenten an Gott verbindet” (246). The notion of a sign production of the good news which describes what the vocation consists in can avoid these false alternatives.

33 The following discussion of the use of $\lambda \alpha \tau$ have covered in our exegesis of Rom 1.18-32.

34 Though one would expect $\sigma \varepsilon \beta \alpha \dot{\alpha} \zeta \varepsilon \sigma \theta \alpha$ t to be accompanied with an accusative indicating the object of reverence. The construction is a zeugma.

35 It may well be the case that such a comprehensive characterisation of a way of life by a manner of worship may work better with monotheism.

36 Worship in a cultic setting would be the paradigmatic example in Jerusalem. In the diaspora, it might be worship at synagogues. 


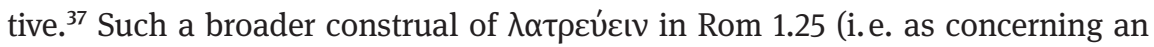
overall way of life characterised by one of its dominant aspects, namely worship

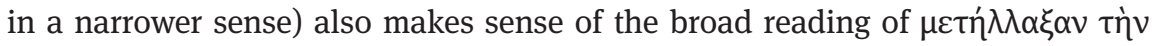

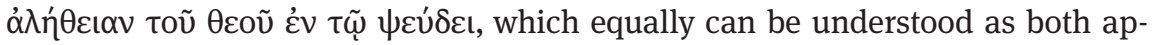
plying merely to the question of the one God and the many gods, or as once more

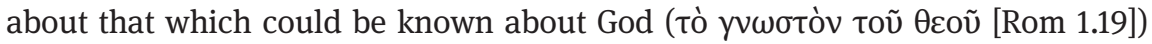
and which should have formed the basis for the right sort of human response. It is then to be understood in a similar manner as in Rom 1.18: those who hold

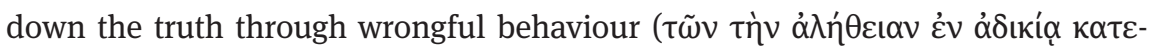

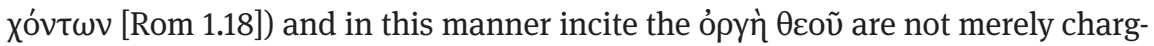
ed with improper behaviour in matters of cult, shrine or "religion". Rather, they are cast as being comprehensively in the wrong, both with regards to God and humans, with the latter as following from the former. This view is not undermined by the context of Rom 1.24, which seems more specific with regards to il-

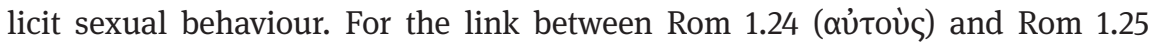
(oiltıveৎ) does not have to be construed as causal ${ }^{38}$ but simply means "as many as" or even "those who". Thus, one does not have to read Rom 1.24-25 as saying there was a consequence for one aspect of life (sexual desire) because of what happened in another (worship in the narrow sense), but can rather more plausibly see it as saying: these humans were given up to their desires (of which the sexual variety would be one notable kind), they who were serving the creature, and thus remaining at the level of sense perception and gratification of bodily and material desire. They were not doing what humans should do and what their specific capacity, the ability to think, might have allowed them to do, but merely operated at the creaturely level, not rising above desires characteristic (according to stereotypes used in some ethical discourse) of animals. ${ }^{39}$ Paul might also have specific scriptural traditions in mind which link idolatry and sexual behaviour. ${ }^{40}$ But even if one can detect and make good sense of more restricted kinds of action being referred to here, it is clear from the larger

37 As we have argued (section 5.2.3). Cf. also the statement of Nebuchadnezzar about praising

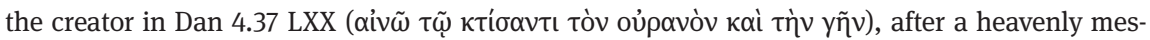

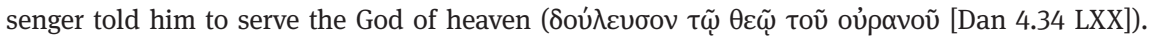
38 As the NRSV does ("because").

39 Cf. e.g. Epictetus 2.9.

40 Cf. for instance the Phinehas episode in Num 25, where divine anger is kindled (25.3) by Israelites cultically venerating (25.3) the Baal of Peor, and where an Israelite and a Midianite woman are killed in their tent in flagrante delicto (25.6-8). Cf. also Solomon's many wives leading him to worship other gods in 1 Kings 11.1-8, as a narrative elaboration of the warning given in Exod 34.16 (cf. 1 Kings 11.2). 
context that a comprehensive behaviour is in view. Many scholars now point to the parallels between Rom 1.18-32 and Rom 12.1-2, and it is now regularly pro-

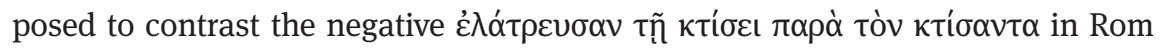

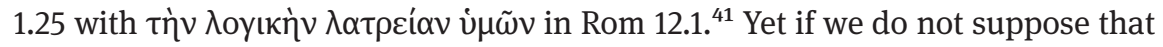
the topic in both is merely the behaviour towards the true God at special occasions but a characterisation of the overall life of humans, which includes "religious" or cultic action as a part, then one can understand both references in a sense that is closely related (even though in Rom 1 the point is stated negatively).

In Rom 9.4, the noun $\lambda \alpha \tau \rho \varepsilon i ́ \alpha$ appears as part of a list (Rom 9.4-5) of honourable characteristics of Paul's fellow Israelites. Paul is thereby describing the Jews such as they are in the present, and in this case the reference of $\lambda \alpha \tau \rho \varepsilon i \alpha$ would likely bring to mind the temple service at Jerusalem and the cultic worship offered there, being the dominant focal point of Israel's worship. On the other hand, it is once more possible to understand $\lambda \alpha \tau \rho \varepsilon i \alpha$ here as more broadly characteristic of an entire way of life than its immediate referent, worship, would suggest, and in this way to confirm our reading of $\lambda \alpha \tau \rho \varepsilon i \alpha$ as service to God. This is so, first, because $\lambda \alpha \tau \rho \varepsilon i ́ \alpha$ is the only item in the list that directly refers to a human action and response. Thus, it alone stands in for the reference to the entire way of life understood as characteristic for the elected people of God. ${ }^{42}$

But also, second, because all the other items in the list point to events in the scriptural past, ${ }^{43}$ and this would make it plausible to expect for $\lambda \alpha \tau \rho \varepsilon i \alpha$ a wider scriptural resonance as well. In the Greek traditions of Israel's scripture, especially the use in the Exodus narrative stands out. There is a recurrent motif in the story about how Moses is the one who is God's agent in leading the people of Israel out of the desert, namely that this is done in order for them to "worship" or "serve" their God in the desert. Thus, when Moses is commissioned to this task in the scene at the burning bush and hesitates, expressing doubts about his suitability, God replies that he will be with Moses, and that the sign that he sent him

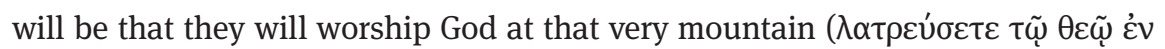

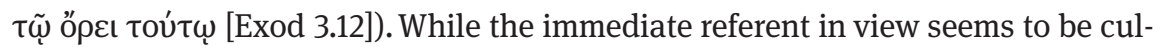

41 As we noted in section 5.2.

42 So also Wolter 2019, 35 who understands the $\lambda \alpha \tau \rho \varepsilon i ́ \alpha$ in 9.4 as a "komprehensive Umschreibung dessen, was Gott von dem Volk einfordert, das er sich erwählt hat”.

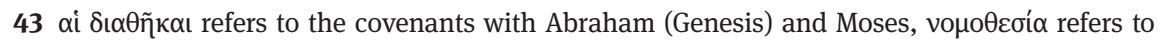

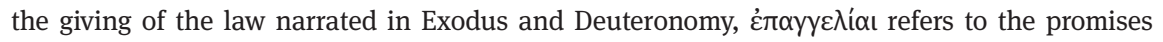

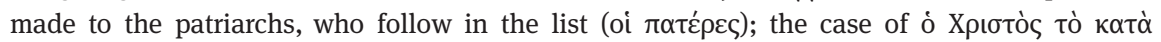

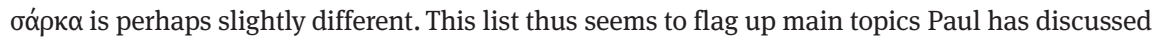
so far: Abraham (Rom 4), the Torah (Rom 7), sonship (Rom 8). 
tic acts such as animal sacrifice, ${ }^{44}$ these acts are not merely incidental, but expressions of what the entire way of life of liberated Israel is about. This can be clearly seen in the recurrent motif of the "reason" offered to Pharaoh, in the name of YHWH, why he must let the Israelites go, namely in order for

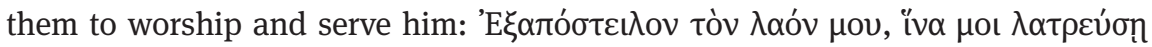
(Exod 4.23). ${ }^{45}$ If this is taken to be a statement of the purpose of their liberation, then it is also a statement about the purpose of their liberated way of life. This way of life is characterised as being such that it allows for the worship in the stricter sense to take place, but also, as a whole, is oriented toward serving the God thus worshipped. Thus, there is in the Greek tradition of Israel's scripture, with which Paul was intimately familiar, a prominent association of the language of $\lambda \alpha \tau \rho \varepsilon v ́ \varepsilon ı v$ with the purpose of the entire liberated existence of the people of God.

This is further confirmed, outside of Exodus, for instance, in the use of $\lambda \alpha \tau \rho \varepsilon \cup ́ \varepsilon ı v$ in Deut 10.12, which, echoing the language of the Shema, expresses comprehensively what Israel must do once it has entered the land. ${ }^{46}$ Detecting a reference to the present temple cult in Jerusalem in Rom 9.4 is not, then, at variance with such scriptural resonances: part of the legitimising function of the

44 As can be seen in the instruction in Exod 3.18 that Moses should tell the elders that the purpose of their journey to the desert is in order to offer sacrifice (ív $\theta \dot{v} \sigma \omega \mu \varepsilon v \tau \tilde{\omega} \theta \varepsilon \tilde{\omega} \dot{\eta} \dot{\eta} \mu \tilde{\omega} v)$. Cf.

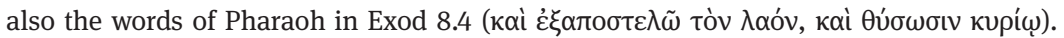

45 Cf. similarly Exod 7.16, 7.26, 8.16, always with $\lambda \alpha \tau \rho \varepsilon v \dot{\varepsilon}$. The context of Exod 10.25-26 makes

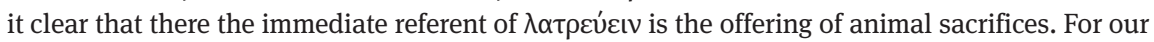
purposes, however, it is important to note two levels of meaning: the immediate referent, which here is cultic sacrifice, and a broader reference to a way of life and its purpose characterised by these cultic acts as particularly important focal points. It is precisely the latter level of meaning on which Paul draws for the meaning of $\lambda \alpha \tau \rho \varepsilon i ́ \alpha$ in Rom 12.1. Cf. also Deut 28.47-48, where the

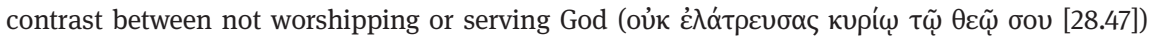

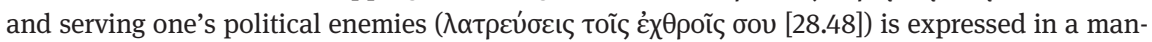
ner that exploits the semantic range of $\lambda \alpha \tau \rho \varepsilon v \varepsilon \varepsilon v$. But also here the verb is used comprehensively to characterise the manner of living as one of disobedience. Cf. also Deut 10.12.

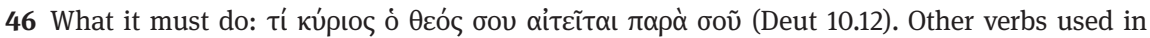
Deut 10.12-13 are best understood not as indicating parts of a whole but rather as profiling as-

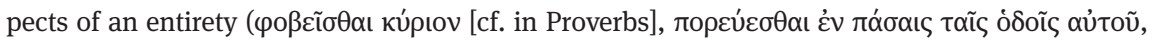

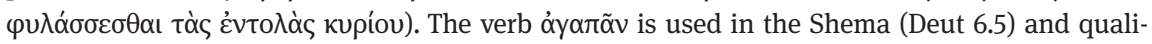

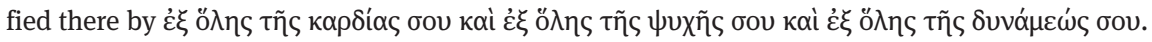

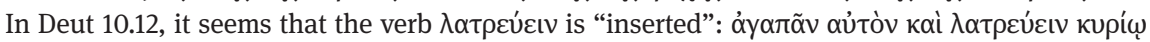

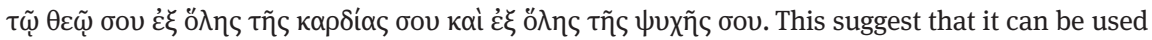
comprehensively to characterise the relation to God to which Israel is called. 
Pentateuchal narrative is precisely to establish how the liberated people wander in the desert and worship in a mobile shrine, until the temple at Jerusalem becomes the exclusive central place for Levitical sacrifice, and thus becomes the focal point of the Jewish way of life and its raison d'être. ${ }^{47}$ Paul is positive about this Jewish $\lambda \alpha \tau \rho \varepsilon i ́ \alpha$ in Rom 9.4, which makes it implausible to read him as engaged in polemics against Jewish cult in Rom 12.1.

Thus, to summarise, we find that Paul's use of $\lambda \alpha \tau \rho$-language in Romans (outside of Rom 12.1) makes it plausible that he can use $\lambda \alpha \tau \rho \varepsilon i \alpha$ in a manner which comprehensively refers to a way of life oriented towards a particular purpose, which focally includes but is not restricted to acts of worship in a stricter sense, but is precisely understood in such a manner as to draw together the meaning and purpose of the entire way of life. In this way it becomes one of the ways in which Paul can speak of a vocation, a purpose of existence. We

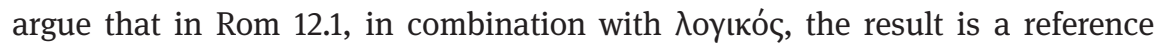
to the human vocation, whose fulfilment is claimed as a possibility in the life of those to which the letter addresses itself.

Our interpretation of $\lambda \alpha \tau \rho \varepsilon v$ ctv is also supported by the way it is used in Phil 3.3, the only other occurrence of the verb in Paul. In a sharply polemical context, he claims for a Christ-followers' "we" that includes mostly Gentiles (who will

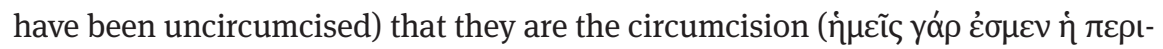
$\left.\tau о \mu \eta^{\prime}\right)$, and characterises them further as those who serve or worship in the spirit

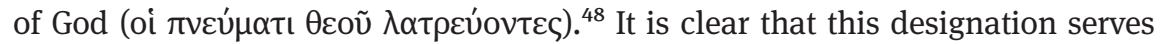
as a contrastive identity statement. This makes it plausible that it is a more comprehensive statement than something to do with what happens, for instance, when the Philippian Jesus-followers gather for a meeting. ${ }^{49}$ Insofar as circumcision functions as the male identity marker within ancient Judaism and thus as a precondition for closer access at the Jerusalem temple, it is noteworthy that "circumcision" in a figurative, and presumably, a "true", sense, is claimed for such as are then characterised by a mode of worship or service. The $\pi v \varepsilon \tilde{u} \mu \alpha \theta \varepsilon o \tilde{v}$ clearly is the spirit of God; what is less clear is whether Phil 3.3 says that the spirit of God is worshipped (as the dative would normally lead one to expect, but which is unusual as a statement) or that the service is enabled and performed through the spirit of God. The latter is more likely because the contrast seems

$47 \mathrm{Cf}$. for instance the reference to Jerusalem, expressed generically to guard against "anach-

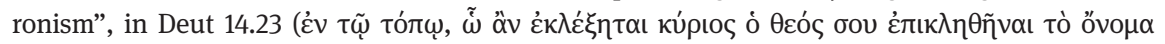

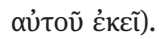

48 Textual variant: $\theta \varepsilon \tilde{\omega}$.

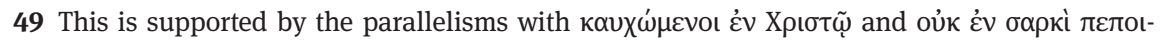
Өótes in Phil 3.3. 
to be similar to the contrast with circumcision such as one finds in Rom 2.25-29: those who, enabled by the Spirit, live in such a way that they serve God, fulfil

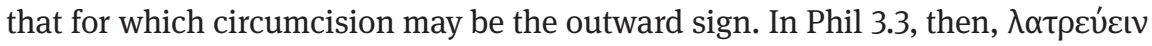
is used to refer comprehensively to the life of those in Christ and to cast it as either a service (implicitly to God) in a mode enabled by God's spirit, or, with an alternative construal, as "worship", where "worship” functions synecdochically, characterising all their actions by means of an important subset. Phil 3.3 by itself does not contain clues that a vocation is in view, but the larger context of the letter makes it clear that Paul thinks about the Christ-followers in Philippi in such terms. ${ }^{50}$ Thus, Paul's use of the word in Phil 3.3 does not of itself indicate a vocation, but rather a service to God which focally contains acts of worship and is important for the articulation of identity.

Thus, we conclude that the Pauline use of $\lambda \alpha \tau \rho \varepsilon u ́ \varepsilon ı v$ and $\lambda \alpha \tau \rho \varepsilon i ́ \alpha$ supports the reading of $\lambda \alpha \tau \rho \varepsilon i \alpha$ in Rom 12.1c as comprehensively referring to a service to God, which includes but is not restricted to acts of worship in a narrow sense. Further, it is open to a framing of a life characterised by such service to God as being in its entirety a service to God or worship - that is, as a response to God which brings the best human beings can offer before him.

\subsubsection{A further confirmation from a passage in Philo}

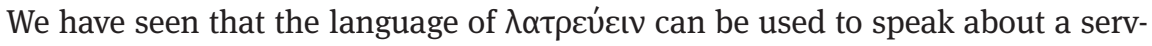
ice to God in such a way as to express the idea of a vocation. There is a passage in Philo's De specialibus legibus that uses the language of $\lambda \alpha \tau \rho \varepsilon v ́ \varepsilon ı v$ in a manner that confirms this, but also combines it with the idea of genuine humanness and applies it exclusively to a group, namely Israel. Philo describes an address to the human mind ( $\delta \iota^{\prime} v o เ \alpha$ ) which identifies, in a paraphrase of Deut 10.12, what is

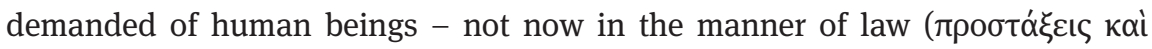

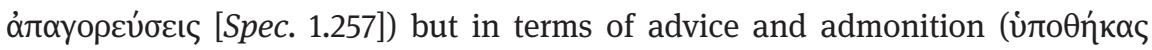

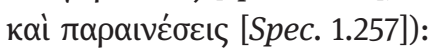

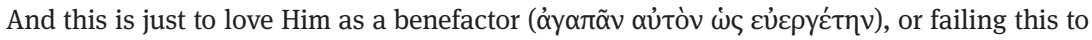

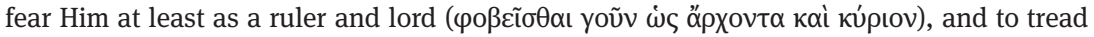
in every way that will lead you to please Him, to serve Him not half-heartedly ( $\lambda \alpha \tau \rho \varepsilon v$ cเv $\alpha \cup \dot{\tau} \tilde{\omega} \mu$ ì $\pi \alpha \rho \varepsilon \varepsilon^{2}(\omega \varsigma)$ but with your whole soul filled with the determination to love Him

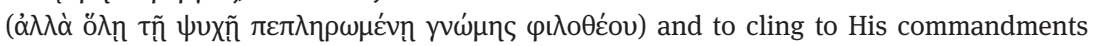
and to honour justice. (Philo, Spec. 1.299) ${ }^{51}$

50 Cf. for instance Phil 1.27.

51 Transl. in this section H. Colson, adapted. 
Philo aims to show that these commandments are not hard or laborious to fulfil

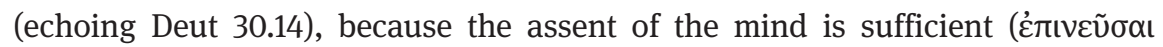

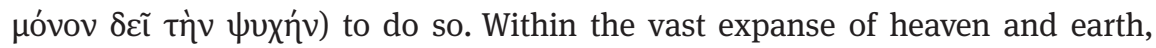
God has chosen for himself a special people:

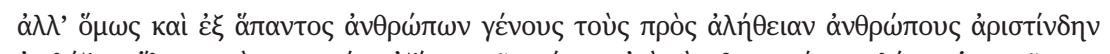

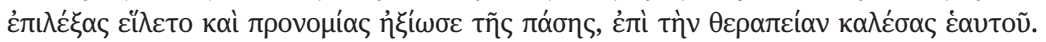

Yet out of the whole human race He chose as of special merit and judged worthy of pre-eminence over all, those who are in a true sense humans, and called them to the service of Himself. (Philo, Spec. 1.303)

This passage is significant, first, because it explicitly uses the motif of genuine

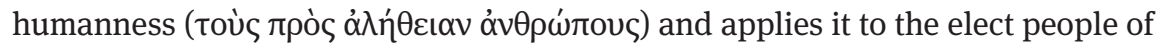
God (Philo usually applies it to the mind alone). Second, because it uses the lan-

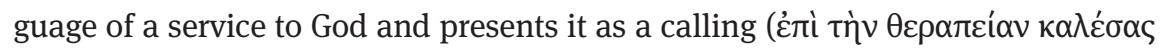
$\dot{\varepsilon} \alpha u \tau o \tilde{)}) .{ }^{52}$ We note that the fact that "calling" language ( $\left.\alpha \lambda \varepsilon^{\prime} \sigma \alpha \varsigma\right)$ is used is certainly fitting for the idea of a human vocation but not a requirement for us to detect our concept of a vocation. While Philo used the verb $\lambda \alpha \tau \rho \varepsilon v ́ \varepsilon เ v$ above, in this passage he uses $\theta \varepsilon \rho \alpha \pi \varepsilon i \alpha$ to express such an idea. Furthermore, this passage is especially important in that it shows explicitly how genuine humanness and the idea of fulfilling a vocation can be coupled.

\subsubsection{Conclusion for $\lambda \alpha \tau \rho \varepsilon i ́ \alpha$}

Thus, we conclude that the language of $\lambda \alpha \tau \rho \varepsilon i \alpha$ and $\lambda \alpha \tau \rho \varepsilon u ́ \varepsilon ı$ can be one of the ways in which Paul speaks of a service to God which corresponds to a calling. It depends on context and upon other qualifications whether we end up with the idea of a singular vocation (such as the one of Socrates ${ }^{53}$ ) or of a particular group (such as the example from Philo we have just discussed) or, as we argue for Rom 12.1, of a human vocation, a calling that is incumbent upon human beings as such (even if it is directly applied, in the context, only to the group addressed, and not to all humans). Such a service is more than merely "the believer's ethical sacrifice", ${ }^{54}$ because while it involves effort and right conduct, the focus is on what the right action is for and what end it serves. Paul's idea in Romans is that human beings have a role in the wider cosmos, and that the Christ event

52 Cf. also Philo, Somn. 1.161 (discussed in section 2.2).

53 Even if Socrates has become exemplary for others, on which cf. Döring 1979; for Epictetus, see Long 2002, 67-96.

54 As Scott 2018 simply takes for granted (e.g. 531). 
has brought about a change of conditions, such that there is now a mode of being human in which this role can be fulfilled. This role is their proper task as human beings and if they fulfil it, they display the genuine humanness which has been revealed in Christ, and, by virtue of their union with him, also becomes a possibility for them. Within the ancient encyclopedia, the force

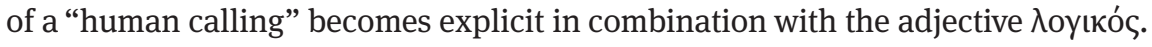

\subsubsection{That $\lambda о$ ¿кós refers to the specifically human capacity on which a vocation is based}

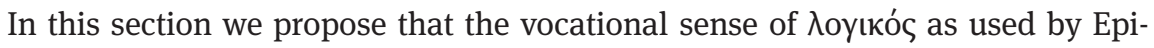

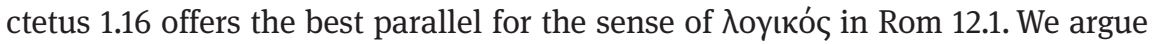
that the word points to the human endowment with reason as that which makes humans human ${ }^{55}$ and to their distinct capacity, on which a role within the cosmos is based.

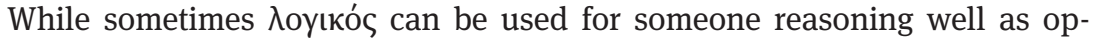
posed to the sense in which every adult human being is endowed with reason, ${ }^{56}$ here the sense refers to the distinctly human capacity. Yet given a protreptic and vocational context, this endowment is also the basis for an aspiration to use it well. For the Stoics, reason within human beings is a divine form, but it is given in a precarious manner, as Forschner describes well: "Im Menschen ist das göttliche Prinzip in seiner höchsten Form als selbstbewusste und selbsttätige Vernunft individuiert" but "er ist [beziehungsweise] hat diese seine göttliche Form in einer Weise, die ihm selbst aufgegeben ist, und die sich selbst unterbieten, depravieren und verfehlen kann."57 Thus, it designates both something on which a calling is based and a norm to which one should aspire.

We have identified two important ideas within ancient thought that are needed in our explanation of what Paul does when he uses reason language in Rom 12.1. The first idea is that reason is the human proprium. The second is that human beings have a task within the cosmos based on their proprium.

Ancient thinkers who hold that human beings have such a task differ in their view of what this task consists in and they use a variety of language and imagery for both. We need to distinguish language used to describe what the task consists

55 Both in the classificatory sense and in an aspirational sense.

$56 \mathrm{Cf}$. the second and the third senses discussed in section 2.1.1. For a similar distinction, see Aristotle, EN 1.7 (the lyre player and the good lyre player).

57 Forschner 2018, 185-186. 
in from language which is used to state that human beings have such a task (or which identifies certain actions as that task).

This distinction is crucial for explaining how our interpretation of $\dot{\eta} \lambda$ oyıkn $\lambda \alpha \tau \rho \varepsilon i \alpha$ in Rom 12.1 differs from other interpretations. For other interpreters, too, rightly point to Epictetus' use of reason language in 1.16 as a parallel to Paul's use of it in Rom 12.1, but understand the parallel differently. ${ }^{58}$

We will now show how this distinction applies to both Rom 12.1 and Epictetus 1.16.20-21. Here are the relevant passages:

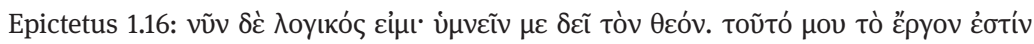

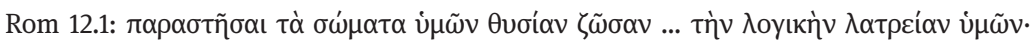

In the Epictetus passage, we see three units. The first (vṽv $\delta \varepsilon \dot{\varepsilon} \lambda$ oyıкó to the specific human capacity on which a task in the cosmos is based. The sec-

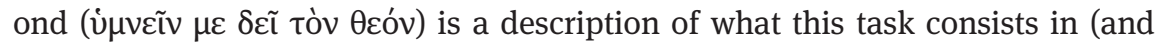

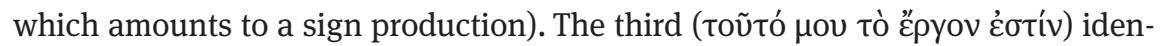
tifies the action described as the task (based on the specific capacity); ${ }^{59}$ it implies that there is such a task.

In Rom 12.1, the same three elements are present. The description of what

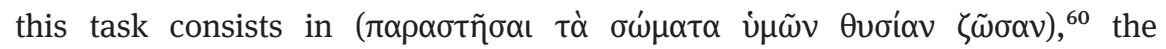

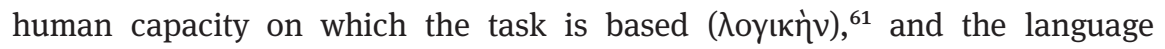
used to identify this description as the task ( $\lambda \alpha \tau \rho \varepsilon i \alpha v)$.

In our analysis of Rom 12.1, Paul's use of $\lambda \alpha \tau \rho \varepsilon i ́ \alpha$ implies that human beings have such a task. This means that we see $\lambda \alpha \tau \rho \varepsilon i ́ \alpha$ primarily as a parallel to है $\rho y o v$,

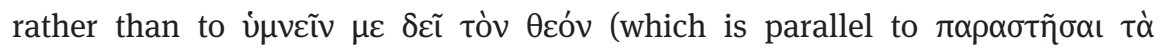
$\sigma \omega \dot{\mu} \mu \tau \alpha)$.

The Epictetus parallel is usually read differently, such that $\lambda \alpha \tau \rho \varepsilon i \alpha$ in 12.1 is

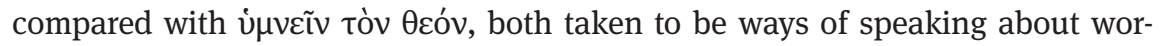
ship. Viewed in this way, Epictetus 1.16 is an example of a text in which the language of 入оуıкós is linked with worship; it is cited for the "idea that worship should conform to reason". ${ }^{2}$

58 E.g. Cranfield 1979, 602; Dunn 1988b, 711. Byrne 1996, 366 seems close to our reading, though the statement is too brief to tell.

59 To be more precise the words $\mu \varepsilon \delta \varepsilon \tilde{~}$ do not belong to the description, but to the identification with the human task.

60 Which we have argued amounts to a sign production.

61 How the adjective can actualise this meaning in Rom 12.1c will be shown in section 6.3.3.

62 Cf. Jewett 2007, 730. 
As an example, we will discuss how Wolter, in the recently published second half of his commentary on Romans, uses Epictetus 1.16.20 to explain what Paul

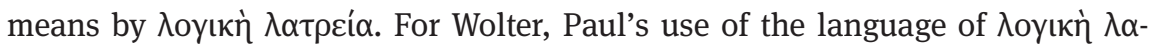
$\tau \rho \varepsilon i ́ \alpha$ in Rom 12.1 draws on a widespread concept of Stoic origin, whose core idea is that the entire cosmos is ordered and permeated by a divine principle

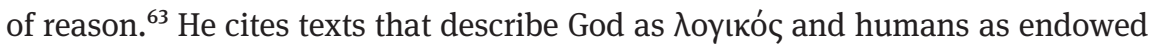
with reason (including Epictetus 2.9.2). Further he cites texts that we have discussed above as describing the idea of a human purpose within the cosmos (Marcus Aurelius 2.16), which he summarises as

Für ihre Lebensführung ist den Menschen darum aufgegeben, dass sie sich der "vernünftigen” Ordnung anpassen, die der Welt eingestiftet ist. ${ }^{64}$

It follows from these ideas, according to Wolter, that

die Gott gemäße Gestalt der Verehrung einen Kult verlangt, der nicht aus dinglichen Opfern besteht, sondern dem Logos-Charakter Gottes dadurch Rechnung trägt, dass er ebenfalls Logos-Gestalt annimmt. ${ }^{65}$

As a footnote to this statement Wolter refers to Epictetus 1.16.20, which he quotes with the following translation (and Greek text elements):

Wäre ich eine Nachtigall, würde ich tun, was der Nachtigall gemäß ist. Wäre ich ein Schwan, was dem Schwan gemäß ist. Jetzt aber bin ich 入oyıкóc: Es obliegt mir, Gott zu pre-

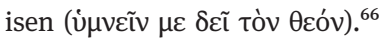

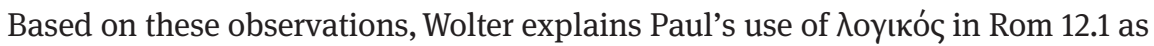
describing a "Gottesdienst, der ohne dingliche Opfer auskommt". ${ }^{67}$

It will be useful to discuss the ways in which Wolter's use of Epictetus 1.16.20 differs from ours in the explanation of Paul's reason language in Rom 12.1c. We will now sketch out the stated and implied assumptions of Wolters explanation and contrast them with ours.

63 Wolter 2019, 253.

64 Wolter 2019, 254.

65 Wolter 2019, 254.

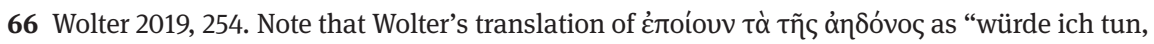
was der Nachtigall gemäß ist” subtly differs from Hard's translation "I would perform the work of a nightingale", which by way of paraphrase better foregrounds the contextual nuance. Wolter's translation is similar to that of Cranfield 1979, 602.

67 Wolter 2019, 254. 
(1) For Wolter, the $\lambda \alpha \tau \rho \varepsilon i ́ \alpha$ in Rom 12.1 predicates a "religiöse Praxis"68 and thus identifies (or at least further circumscribes) what it is that should be done (corresponding to "what the task consists in", in the distinction drawn above). Our interpretation takes $\lambda \alpha \tau \rho \varepsilon i ́ \alpha$ to refer to the fact that there is such a task, a calling, a vocation, without a specific restriction to the domain of actions we might class as "religious". ${ }^{69}$ Thus $\lambda \alpha \tau \rho \varepsilon i ́ \alpha$ describes a service to God, which may consist of ethical actions or of acts of worship (in the narrow sense), but which does not serve here to circumscribe the field of action. It qualifies a certain conduct as done in view of God, but does not restrict it to "religious" acts.

(2) When Wolter reads Epictetus 1.16 .20 as a parallel to Rom 12.1c, he assumes that Epictetus speaks about what true worship ("religion") looks like.

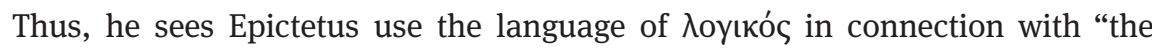

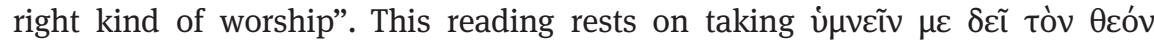
(1.16.20) as being parallel to $\lambda \alpha \tau \rho \varepsilon i ́ \alpha$ in Rom 12.1c. And it understands ن̀ $\mu v \varepsilon \tilde{v} v$ $\mu \varepsilon \delta \varepsilon \tilde{\imath}$ Tòv $\theta \varepsilon o ́ v$ as describing the form worship must take if it is to be appropriate ("Given that I am 入oyıкós, the appropriate form of worship for me must be prais-

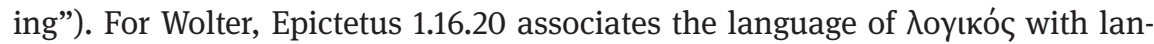

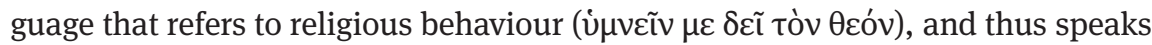
about the religious praxis that befits a certain $\lambda$ oyıкós nature; in the light of the parallel as so understood Paul also speaks about religious praxis ( $\lambda \alpha \tau \rho \varepsilon i \alpha)$ and uses the language of $\lambda$ oyıкó so characterise religious praxis that is appropriate. What makes it appropriate, in Wolter's interpretation, is that it is a cult whose

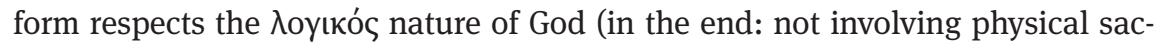
rifice). ${ }^{70}$

We note that there is a slight mismatch in Wolter's use of Epictetus 1.16 .20 as a parallel, in that he takes the parallel to support the idea that proper worship

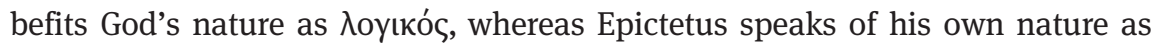
入оyıкós. But presumably, in having cited some of the passages which show that for the Stoics, human and divine reason are linked, and that proper human conduct must conform to the nature of the whole and to their own nature

68 Wolter 2019, 255.

69 In his comment on the meaning of $\lambda \alpha \tau \rho \varepsilon i ́ \alpha$ in Rom 9.4, Wolter is closer to our own meaning when he writes that it is a "komprehensive Umschreibung dessen, was Gott von dem Volk einfordert, das er sich erwählt hat" (Wolter 2019, 35). The concrete examples for what is included under this description, namely not only the temple cult but die "Gesamtheit von Israels exklusivem Ethos”, which includes cultic sacrifice, keeping feasts and holidays, fasting and praying (Wolter 2019, 35), give an indication of what he counts as "religiöse Praxis" (Wolter himself refers back to this passage in his commentary).

70 See the quotation above. 
(DL 7.88), Wolter thinks that this difference can be neglected. ${ }^{71}$ And perhaps it would not amount to very much, if one could safely assume that Paul shared the Stoic metaphysical view that divine reason and human reason are substantially linked..$^{72}$ But that assumption is implausible, and Wolter seems to distance himself from ascribing the metaphysical implications about immanent world reason and human reason to Paul when he writes that Paul only draws on the language in which the Stoic view would have been formulated ("unter Rückgriff auf die Sprache jener Vorstellung”). ${ }^{73}$

But as we have shown in chapter 4, the context of Epictetus 1.16 and the details of 1.16.20 - 21 make it clear that Epictetus is speaking about the human call-

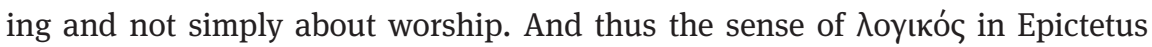
1.16 should be taken to describe the subject of the human vocation in respect of its enabling capacity. If this is, as we argue, the sense in which Paul uses

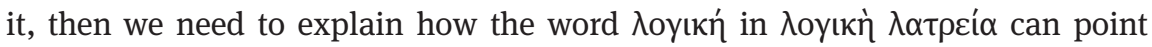
to the subject of the $\lambda \alpha \tau \rho \varepsilon i \alpha$, which is what we do in the next section.

\subsubsection{That the combination with גоүıкós highlights the human subject of $\lambda \alpha \tau \rho \varepsilon i ́ \alpha$}

In Rom 12.1c the action noun $\lambda \alpha \tau \rho \varepsilon i ́ \alpha$ describes a service to God which is a vo-

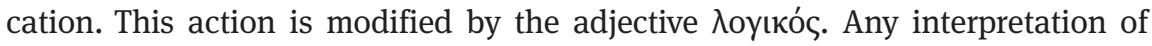
Rom 12.1c needs to make a decision in what way it takes the adjective to modify the noun. Most interpretations are not thematically aware of this step and in this way they have missed an option which we propose as a solution. An adjective can modify a noun in many ways - comparable to a genitive attribute for which exegetes have developed an array of categories in which they then frame their disputes (subjective, objective, partitive and so on). As one can wit-

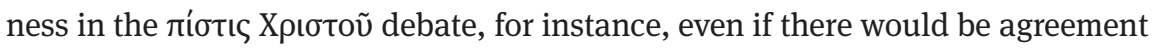
on the correct label for the genitive, the debate would not be settled, because there is still room for divergent interpretations. But the point is that something

71 Dunn similarly combines these elements when he explains "As such it [namely the word $\lambda$ оуєкóৎ, SD] marks out what is appropriate to man, in distinction from beasts, and what relates him to God" (Dunn 1988b, 711).

72 The interpretation of Thorsteinsson seems to come close to assuming this (Thorsteinsson 2010, 142-143).

73 Wolter 2019, 255 (though he does not spell out how this statement relates to the material he cited earlier). Cf. for a similar move, though in service of a different interpretation, Reitzenstein 1927, 331. 
similar happens with adjectives ${ }^{74}$ and this needs to be made explicit for a proper explanation of Paul's reason language in Rom 12.1.

\subsubsection{What adjectives can do to action nouns}

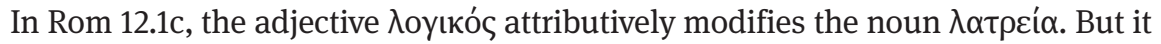
can do this in different ways, as the following reflection shows.

An action can be characterised in several ways, corresponding to its possible semantic roles. Thus, an action has a subject, is performed in certain circumstances (place, time, occasion), in a certain manner, can have a direct object, can be done for a certain purpose, for the benefit or disadvantage of someone else, and so on. If an action is expressed by means of an action noun, then an adjective could, in principle, describe any of these aspects (e.g. "friendly fire”, "parliamentary scrutiny").

The point we are making here is that an adjective which modifies a noun expressing an action could semantically describe any of the semantic roles involved in an action, or the consequences, circumstances, and the manner of the action.

An action can also be compared, evaluated, approved or criticised from an external standpoint; more generally, by means of an adjective a broad range of statements could be made about the action. This applies directly to the interpre-

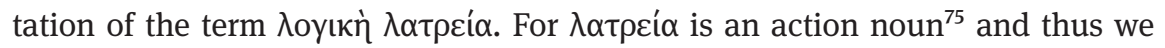
could theoretically expect the characterisation of $\lambda \alpha \tau \rho \varepsilon i \alpha$ by means of this adjective to tell us about any of the semantic roles implicit in the $\lambda \alpha \tau \rho \varepsilon i^{26}$ or the mode of action or some judgement about the action by the speaker (and there could be a combination: an indirect characterisation of an action by means of a direct characterisation of one of the semantic roles of the action). ${ }^{77}$

74 In fact, often what one might say with an adjective relating to a noun could also be expressed via a genitive form of the noun (e. g. brotherly love is the love of a brother).

75 The noun refers to an action. The grammatical category nomen actionis needs to be distinguished from the term action noun in some contexts: we use nomen actionis to designate a class of word formation (nouns ending in -ía for instance), which nouns may often be action nouns, but not necessarily so (if the meaning of a term that used to be an action noun still has the lexical form of a nomen actionis, but can be used in ways other than to express an action).

76 Sometimes also called syntactical roles in different theoretical contexts.

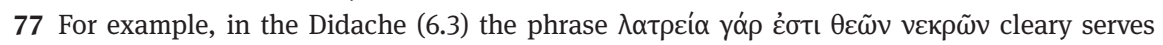
negatively to qualify eating meat offered to idols. It does so by negatively characterising the recipients of such a $\lambda \alpha \tau \rho \varepsilon i ́ \alpha$ as dead (vعкрós). This is not quite the same as an adjective modifying

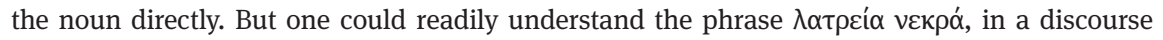


We will show this point by offering several concrete examples in which an adjective modifies the action noun $\lambda \alpha \tau \rho \varepsilon i ́ \alpha$. An example in which an adjective expresses a third-party judgment of an action can be found in the mouth of the choir in Euripides' Troiades:

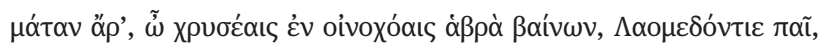

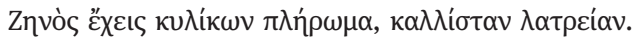

It is for nought, son of Laomedon, you that go with delicate step amid the ewers of gold, that you have the office of filling Zeus' cups, service most noble. (Euripides, Troiades $820-823)^{78}$

This example is illuminating. The choir poetically addresses the cupbearer of Zeus, Ganymede, describes what his office includes as tasks, the filling ( $\pi \lambda \eta^{\prime}-$ $\rho \omega \mu \alpha)$ of the cups, but calls this service ultimately pointless, despite its being

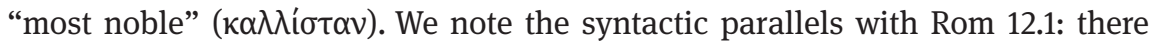

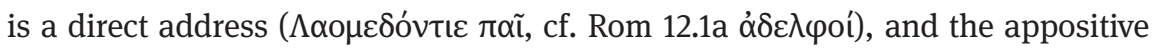
$\kappa \alpha \lambda \lambda i ́ \sigma \tau \alpha \nu \lambda \alpha \tau \rho \varepsilon i ́ \alpha v$ modifies the entire preceding clause, identifying the description of the task as an office, while at the same time offering a comment on this office by making a positive value judgment. ${ }^{79}$

An example in which the adjective indicates the person for the sake of which the service is performed (the recipient of the worship or the one for the benefit of whom the service is performed) can be found in Euripides' Phoenissae. The choir, consisting of Phoenician maidens, who have been dedicated by the inhabitants of Tyre to the temple of Apollo in Delphi, speaks, using the first person singular,

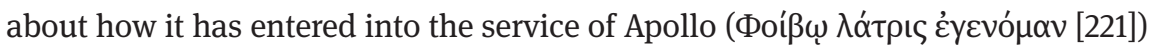
and a few lines later again refers to the service of Apollo (in the objective sense)

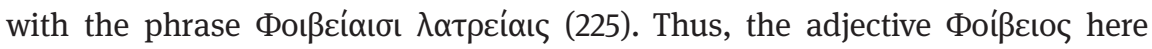
modifies the noun $\lambda \alpha \tau \rho \varepsilon i ́ \alpha$ in such a way as to point to its object or recipient

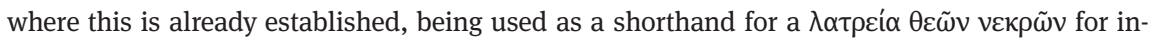
stance. For a positive characterisation one could point to Gregory of Nyssa, De pythonissa ad

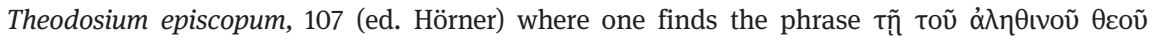
$\lambda \alpha \tau \rho \varepsilon i ́ \alpha$.

78 Transl. D. Kovacs, adapted.

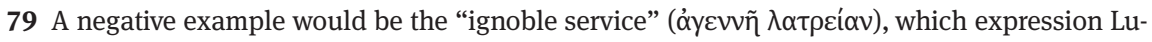
cian (Apologia 4) uses to criticise the contradiction between life and doctrine in someone who once in writing had condemned what he then in old age chose for himself, namely to fall for the power of a rich man. 
(the subject of the service being the maidens). The case of an adjective derived from a name makes it particularly easy to spot. ${ }^{80}$

An example where the $\lambda \alpha \tau \rho \varepsilon i ́ \alpha$ is modified by an adjective that points to its subject and characterises the $\lambda \alpha \tau \rho \varepsilon i \alpha$ can be found in Aeschylus' Prometheus vinctus, where the punished Prometheus replies in a heated exchange to the messenger of Zeus, Hermes, that he prefers his own unfortunate situation to the serv-

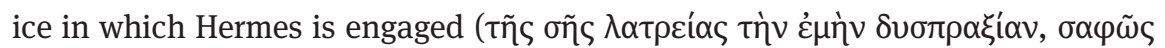

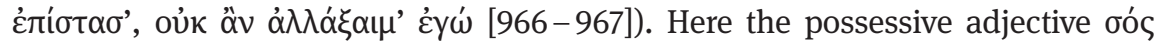
points to the subject of the $\lambda \alpha \tau \rho \varepsilon i \alpha^{81}$

An example in which there is a modification of $\lambda \alpha \tau \rho \varepsilon i \alpha$ which explicates in what kind of acts it consists can be found in 3 Maccabees 4.14, where the hard

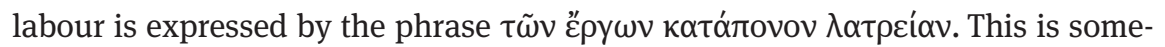
what pleonastic, as already $\lambda \alpha \tau \rho \varepsilon i ́ \alpha$ can mean hard labour. However, adding

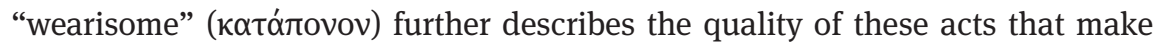
up the $\lambda \alpha \tau \rho \varepsilon i \alpha$, namely that they are taxing for those who perform them. ${ }^{82} \mathrm{Im}$ plicit in this is of course a negative valuation.

An example in which the adjective serves to characterise the manner of the $\lambda \alpha \tau \rho \varepsilon i \alpha$, not concretely as to the actions involved, but for the purposes of an external comparison, is the phrase $\sigma u \mu \beta о \lambda \iota \kappa \tilde{\Upsilon} \varsigma ~ \lambda \alpha \tau \rho \varepsilon i \alpha \varsigma$ in Eusebius, Hist. eccl. 1.3.4, where Jewish worship is claimed to be a symbol of the "true piety" coming later in the form of Christian worship. Some interpretations of Rom 12.1c as a "spiritual worship" in effect would understand the way the adjective modifies the noun in a similar way.

Quite often the characterisation and the evaluation blend. Examples include

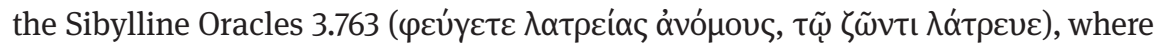
the unlawful worship practices are clearly something to be avoided and hence characterised negatively. The implicit contrast is with service to a living God.

An action can also be characterised by the attitude or emotions or the accompanying thought of the one who performs an action. An example would

80 While the adjective here serves to indicate for whom the service is, this would often be expressed by a noun in the genitive, e.g. in Plutarch, Adul. amic. 56E ( $\theta \varepsilon \tilde{\omega} v \lambda \alpha \tau \rho \varepsilon i ́ \alpha v)$. By contrast, in the (spurious) Consolatio ad Apollonium [Plutarch, 114D], bodily existence itself can be cast as a (labourious) service, from which one is to be freed, and for this a genitive is used, which could

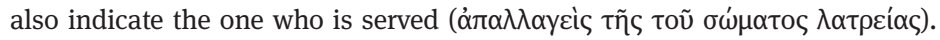

81 What this $\lambda \alpha \tau \rho \varepsilon i ́ \alpha$ consists in (being a faithful messenger to Zeus) is the basis of Hermes' sarcastic response, which trades on the meaning range of $\lambda \alpha \tau$ teía in calling Prometheus' punishment of being bound to a rock a state of $\lambda \alpha \tau \rho \varepsilon v i \varepsilon ı$, with the rock ironically cast as the recip-

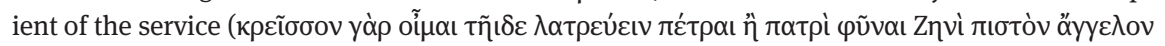
[Aeschylus, Prom. 968-969]).

82 The word हैpyov can itself be used to express hard work (e.g. Xenophon, Mem. 4.6.1). 
be Philo, Sacr. 84, where knowing how to divide the genus virtue into the species of the "cardinal virtues" allows one to serve virtue "voluntarily" or "willingly"

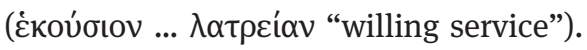

Thus, we have distinguished several different categories in which way may

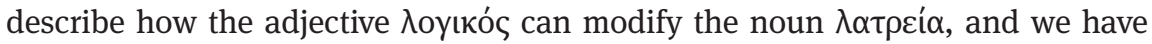
shown the need for such distinctions by means of examples.

\subsubsection{How other interpretations map onto these categories}

Before we discuss our own solution, we will point out how some of the solutions put forward by other interpreters map onto the categories developed in the pre-

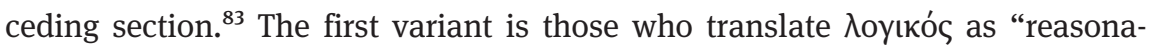
ble". ${ }^{84}$ Thus, the word is understood to function as a third-person evaluation of $\lambda \alpha \tau \rho \varepsilon i \alpha$, amounting to a statement that this act is "reasonable," i.e. an act for which good reasons can be given, which is defensible, in keeping with reason and so on. ${ }^{85}$ Interpretations which assume that the topic of Rom 12.1 is the true cult or worship, and see Rom 12.1c as a reflex of the fact that Christ-followers do not participate in the cult of the polis, would then see Paul as affirming that the practices which make up Christ-followers' service are not something strange or silly, but rather "reasonable". ${ }^{86}$ Another variant is that this $\lambda \alpha \tau \rho \varepsilon i ́ \alpha$ is one which is "the rational and logical response to what Christ has already done in Christ"; ${ }^{87}$ thus, one understands Paul to say with Rom 12.1c: this is the behaviour which follows from my argument so far. ${ }^{88}$ Other interpretations see Paul as making a deliberate point about the body: “offering one's body to God [is] the appropriate kind of worship". ${ }^{89}$ These take $\lambda \alpha \tau \rho \varepsilon i ́ \alpha$ to indicate a topical question (what is the right kind of worship) and Paul to hint at an answer in Rom 12.1b. The adjective 入оуıкós here again functions as a third-party evaluative statement; in this

83 Cf. our discussion in section 1.3.

84 Discussed by Scott 2018, 517-519.

85 Longenecker $(2016,921)$ understands "Paul's statement ... in Rom 12.1 as follows: it is eminently reasonable, both intellectually and spiritually, for believers in Jesus ... to dedicate themselves wholly to God."

86 This is how Gupta 2010 seems to understand it: "worship that makes sense”.

87 Hiebert 1996, cited after Scott 2018, 517 n. 104.

88 Cf. the paraphrase "the worship to which our argument points" offered by Wright 2002, 705, though not fully affirmed (Longenecker's quotation of Wright is misleading in this regard; moreover, it is not verbatim [2016, 920]).

89 Wright 2002, 705 (by implication). 
variant it is taken to be statement about what is genuine ("true, appropriate"), in implicit or even explicit contrast to other forms of worship.

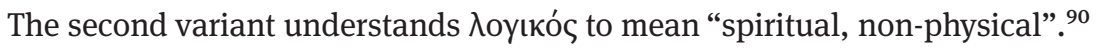
Here Paul is seen as contrasting what Christ-followers do in their times of gathered worship with what happens in cultic worship involving the sacrifice of animals (as something material, physical, "bloody") or some other offerings (nonbloody, but material). ${ }^{91}$ Paul is characterising their worship as not involving such material offerings. Thus, in this variant the manner or mode of the exercise of the action is described as not involving material sacrifice. A clear example where the topic is indeed worship and where the mode in which this worship should proceed is thematised explicitly is Philo, Spec. 1.272:

And indeed though the worshippers bring nothing else, in bringing themselves they offer the best of sacrifices, the full and truly perfect oblation of noble living, as they honour with hymns and thanksgivings their Benefactor and Saviour, God, sometimes with the organs of speech, sometimes without tongue or lips, when within the soul alone their minds

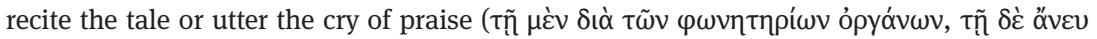

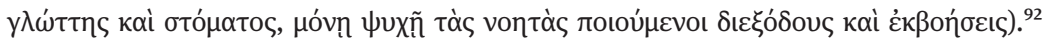

Though the concrete solution is different, in a similar manner Scott argues that $\lambda$ 入уıкó describes the kind of acts of which the $\lambda \alpha \tau \rho \varepsilon i ́ \alpha$ consists, ${ }^{93}$ namely that it is performed by actively reasoning. Scott claims as a result of his semantic investigation that "when human actions are called 入oyıкós, they are consistently either performed by thinking rationally or guided by rational thought". ${ }^{4}$ For Scott the "believer's ethical sacrifice" is characterised by Paul explicitly as worship that consists of acts that involve reasoning. Similarly, Keener takes the adjective to describe the manner in which the $\lambda \alpha \tau \rho \varepsilon i \alpha$ is to be performed: "in Romans 12.1, the way one offers one's body as a sacrifice to God is rationally, through reason - one's mind dictates how the body will serve." 95 In the same vein is Byrne's proposal that the adjective tells us that the "worship" is "proceeding from that which is distinctive of human beings as rational, reflective creatures whose highest powers are engaged in the homage they bring to their Cre-

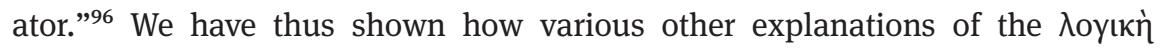

90 Cf. Scott 2018, 519-520.

91 On the various types of sacrifice see Young 1979.

92 Transl. H. Colson.

93 Scott refers to the "believer's ethical sacrifice", to which the $\lambda \alpha \tau \rho \varepsilon i ́ \alpha$ refers back.

94 Scott 2018, 517-518.

95 Keener 2016, 152.

96 Byrne 1996, 363. 
$\lambda \alpha \tau \rho \varepsilon i ́ \alpha$ implicitly answer the question of how the adjective modifies the noun. This point is not usually considered by interpreters, but is important for our own proposal.

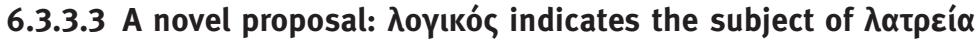

In this section, we offer our own solution, which involves a novel grammatical

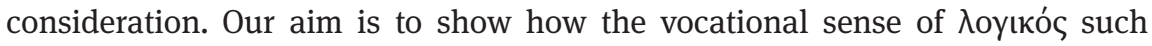

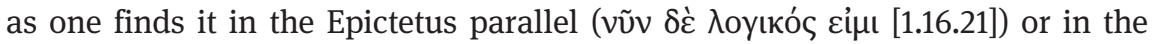

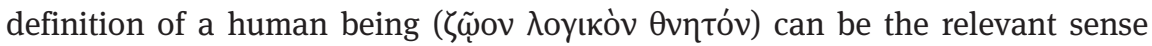
in Rom 12.1c.

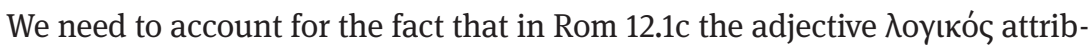
utively modifies the noun $\lambda \alpha \tau \rho \varepsilon i ́ \alpha$, whereas in Epictetus 1.16.20 the word is used

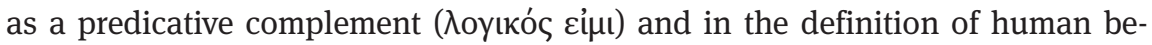

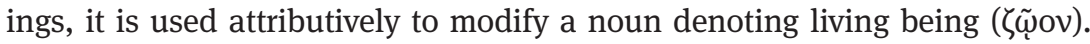

This is where the categories we developed above come into play. We recall that the noun $\lambda \alpha \tau \rho \varepsilon i ́ \alpha$ is an action noun, designating an action with a noun for which the cognate verb would be $\lambda \alpha \tau \rho \varepsilon v$ cıv. As designating an action, the noun implies a subject of the action it expresses. In Epictetus 1.16, 入оуıкós expresses the human subject in its specificity, ${ }^{97}$ and in this sense, we suggest, is it also used in Rom 12.1c.

If the action noun is used to denote a concrete action in a particular instance (the killing of Caesar) one would expect a corresponding concrete subject (Cassius, Brutus and the others). If, on the other hand, the action noun is used to denote a typical activity, one would expect, correspondingly, the typical subject of that action. For example: the (Stoic) practice of anticipating potential misfortune (praemeditatio futurorum malorum) ${ }^{98}$ would lead one to expect as subject of the action someone acquainted with Stoic philosophy.

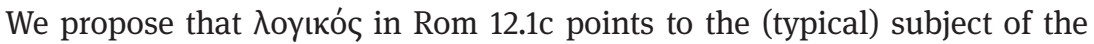

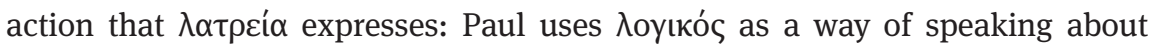
what is characteristically human, their endowment with reason, and thus he indicates that it is the $\lambda \alpha \tau \rho \varepsilon i \alpha$ (the vocation, that is the task to which the subject of the action is called) which befits all those who are 入оуıкós, namely human beings. ${ }^{99}$ No commentator known to me has seen this problem in these terms and hence none has proposed this kind of solution. ${ }^{100}$

97 As we have seen in section 4.4.2.

98 For the term cf. Cicero, Tusc. 3.29.

99 The context makes it clear that human beings are in view, even if in ancient ontologies there is room for 入oyıká which refer to higher beings or stars, as we have seen in section 2.2.6.2. 
The adjective $\lambda$ oyıкós thus modifies the noun by identifying the subject of the action and thereby points to the well-known peculiarity of human beings in ancient discussion, the basis, as the specifically human characteristic, for their specific role in the cosmos. In this way, it would define both the subject of the action and through this, also the action. And because $\lambda \alpha \tau \rho \varepsilon i \alpha$ can be used, as we have shown, to refer to a service to God which is one's vocation in life, these terms come together, in our interpretation, to mean the "human calling" or "the human vocation", that life of service to God to which human beings are called.

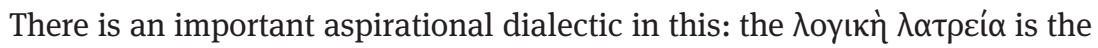
service to which all rational mortal animals are called. But because a rational nature needs to exercise reason properly for it to realise that which it is meant to realise, the $\lambda$ оуєкท $\lambda \alpha \tau \rho \varepsilon i ́ \alpha$ in a sense also marks the ideal to which these be-

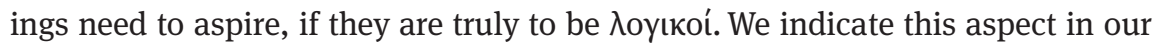
translation by speaking of the "truly human vocation": it is a human vocation in one sense because it is a task that is incumbent upon all human beings, but it is a human vocation in another sense because only when they fulfil it or strive to do so, are they becoming the genuinely human beings they are meant to be.

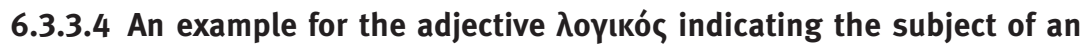 action noun in Diogenes Laertius}

We have thus proposed to read the adjective $\lambda$ oyıкós as indicating the subject of the $\lambda \alpha \tau \rho \varepsilon i ́$ in Rom 12.1. But are there other clear examples in which the adjective $\lambda$ 入уıкós modifies a noun attributively and the text gives indications that the

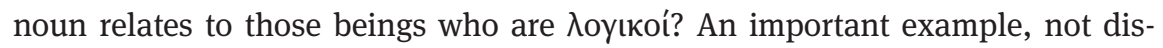
cussed in the commentaries, can be found in the seventh book of Diogenes Laertius' Vitae philosophorum, where the Stoic teachings are summarised. In his discussion of their logical teachings, Diogenes Laertius sets out to quote a section of

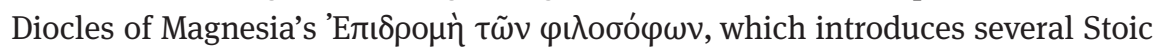
divisions of the $\varphi \alpha v \tau \alpha \sigma i \alpha \mathrm{l}$, distinguishing for instance between those which are $\alpha i \sigma \theta \eta \tau$ เ $\alpha i$ and those which are not. The source then proceeds to another division of the $\varphi \alpha v \tau \alpha \sigma i \alpha$, which is the one that is relevant for our purposes:

100 That the adjective $\lambda$ oyıкó in Rom 12.1 points to human beings precisely as beings endowed with reason is noted, correctly in our view, by Fitzmyer 1993, 637-639, Byrne 1996, 362 and reflected in the translations of the JB and the NJB (though their resulting interpretation is different). It is also implicit, though as part of a very different interpretation in the paraphrase of

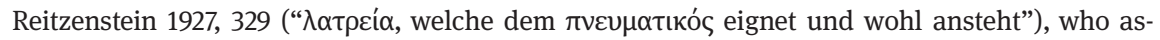

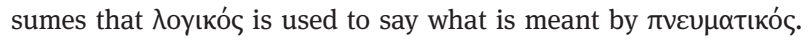




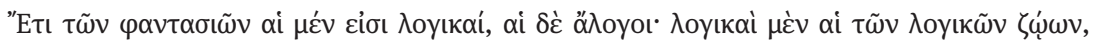

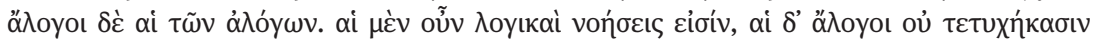
óvónatos.

Another division of presentations is into rational and irrational, the former being those of rational creatures, the latter those of the irrational. Those which are rational are processes of thought, while those which are irrational have no name. ${ }^{101}$
\end{abstract}

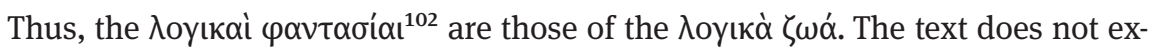

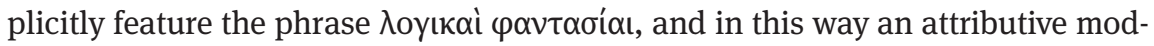
ification of a noun by the adjective $\lambda$ oyıкós. But the predicative use of the adjec-

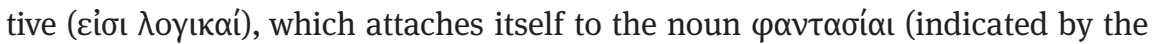

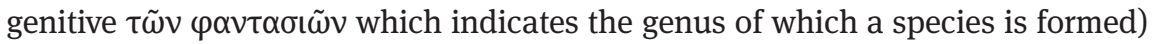

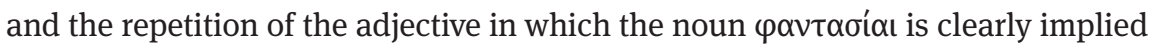

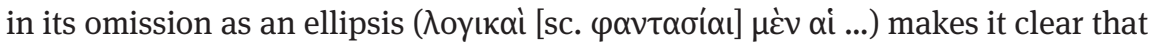

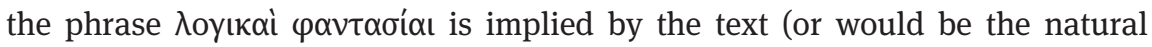
technical term to refer to this kind of $\varphi \alpha v \tau \alpha$ oía). Though in many senses of the word $\varphi \alpha v \tau \alpha \sigma i \alpha$ its verbal force is negligible, at least formally it is a verbal noun of $\varphi \alpha v \tau \alpha \dot{\zeta}(0 \mu \alpha \mathrm{l}$, an act, so to speak, of placing (or having placed) before the mind. ${ }^{103}$ And thus, we have an instance here of an action noun ( $\left.\varphi \alpha v \tau \alpha \sigma i \alpha\right)$ that is qualified restrictively by the adjective $\lambda$ oyıkó in such a way as to point to the subjects of the action which the action noun designates: humans as ra-

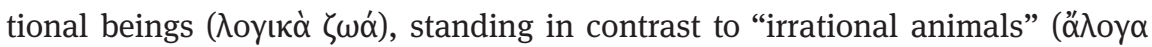
$\zeta \omega \alpha \dot{\alpha})$. Thus we have here, we suggest, a grammatical parallel for the function

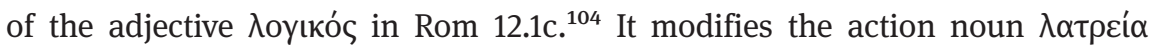
by binding it to its proper subject, namely, human beings: they are identified by the property which marks them as distinct from the other creatures.

\title{
6.3.3.5 Meeting objections to our proposal
}

It might be objected to our grammatical solution that in Rom 12.1c ( $\lambda \alpha \tau \rho \varepsilon i ́ \alpha v \dot{v} \mu \tilde{\omega} v)$ the possessive pronoun $\dot{v} \mu \tilde{\omega} v$ already expresses the subject of the $\lambda \alpha \tau \rho \varepsilon i ́ \alpha$. By way of answer we note that $\lambda$ oyıkós does not identify an individ-

101 DL 7.51. Transl. R. D. Hicks.

102 On "rational presentations", cf. Inwood 1985, 57-59. According to Inwood, 276 n. 98, the reading here adopted is supported by Kerferd and Imbert, but against Long 1971.

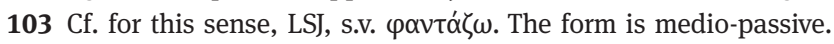

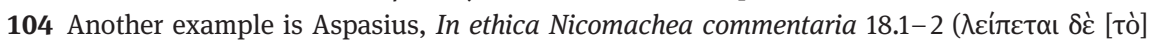

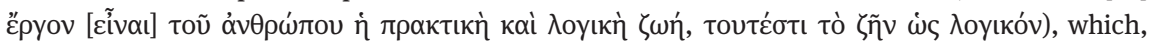
as we have seen, comments on Aristotle's function ("ُpyov) argument (the purpose of something is based on its peculiarity). 
ual in its singularity or a specific group within a category, but refers to a typical subject, a class. This then also inflects the meaning of $\lambda \alpha \tau \rho \varepsilon i \alpha$, which is no longer a concrete action done at a specific point in space and time, but a basic task, a vocation. ${ }^{105}$ It is precisely that task with which those are charged who are $\lambda$ oylкoí, not in the sense of those who are particularly adept at the finer points of manipulating hypothetical syllogisms, but human beings generally. And this combination of a task that befits human beings as such is what is then identified as "yours": this is your human calling, your service to God to which you are called as human beings. ${ }^{106}$

Another objection might be: would Paul have used this form to indicate the subject in such manner? Would he not have expressed such a point in the form

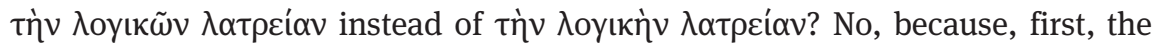

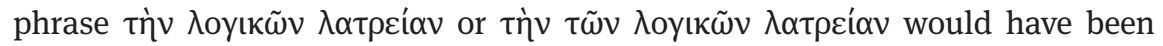
likely to be misunderstood as indicating the object of worship, that is, as a worship directed towards rational things or beings. ${ }^{107}$ And second, if understood as a subjective genitive, this variant would interfere with the pronoun $\dot{v} \mu \tilde{\omega} v$ in a way the formulation with the adjective does not, because it combines to form a concept, the human vocation as rational beings, which can then be ascribed to those addressed via the pronoun $\dot{v} \mu \tilde{\omega} v$.

There is a deeper dialectic at work here which has to do with the nature of a calling based on a certain capacity: a calling needs to be realised and only the realised form of a calling is that which truly deserves the name, towards which the realisation is striving. But the basis is the capacity (or at least the capacity to develop the [full] capacity) which identifies human beings as those endowed with reason, whether or not they fully live up to the calling which follows from this endowment (and thus are "fully human" or "truly human"). Thus, the wise man and the fool are both 入оyıкós in the sense of the definition, but only the wise man is it also in fully realised actuality. In the same manner,

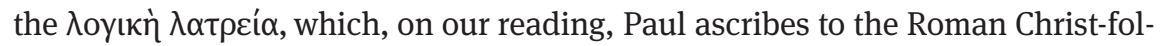
lowers as theirs for the taking, is such that it is both something which applies to them by virtue of their being the beings they are, ${ }^{108}$ but also an aspiration and a norm to which they have to live up to, and only by having become those who do

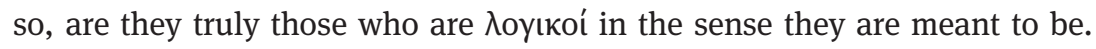

105 Of course, the fulfilment of the task does take place in space and time.

106 The $\dot{u} \mu \tilde{\omega} v$ in Rom 12.1c is a further problem for Scott's reading: it is unclear why a statement that an action involves acts of reasoning should be called "yours".

107 For the construction with a genitive, cf. the above cited example (Plutarch, Adul. amic. 56E). 108 With the qualification we make below. 
There are important differences between the Stoic conceptions and Paul's when it comes to the human endowment with reason and what it means to fulfil the role in the cosmos based on it. First, it is not clear whether Paul subscribes, as the Stoics do, ${ }^{109}$ to a view that reason is something which human beings only develop when they are about seven years old. But this would not matter in any case, as Paul does not have to share the specific assumptions that go with Stoic conceptions about the nature of rationality, either in humans or in that rationality which pervades the cosmos.

Second, for the Stoics, the human role in the cosmos, based on the endowment with reason, is something which can be fulfilled - insofar as the wise man who fulfils it is not merely an unreachable ideal - based simply on that endowment (and given the right instruction, training, helped by precepts), whereas for Paul, what is needed is a transformation of the subject by baptism and all that this entails. ${ }^{110}$ Paul does not explicitly spell out how the conditions have changed such that human beings, in his view, now are able to fulfil it; how, that is, the holy Spirit or the "spirit of Christ" are necessary, or how the category of participation or a particular relation to the messiah, Jesus, is required. ${ }^{111} \mathrm{He}$ simply assumes that it is now possible to live in the required manner. But that does not mean that this transformation moves them away from the "natural" rationality, that which, within the ancient cultural encyclopedia Paul shares, makes human beings human. It means that it has now become possible to fulfil the aspirations to genuine humanness to which they were called all along.

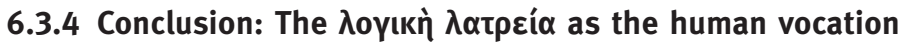

What our exegetical demonstration has thus shown is that the $\lambda$ оуıй $\lambda \alpha \tau \rho \varepsilon i \alpha$ makes excellent sense in terms of the semantics of its terms and in their precise combination as a way of explicitly naming the idea of a "human calling" such that the purport of the statement in Rom 12.1c should be translated as something like "which is your human calling” (or: "your truly human calling”).

109 Cf. Frede 1994.

110 Thorsteinsson gets at a similar point, when he writes: "Proper morality is seen, in [Stoic theology], as a consequence of God's creation of humankind and the nature of that creation, and, in [Christian theology], as a response to God's (recent) actions in the world on behalf of humankind" (2010, 141). However, Thorsteinsson understands Rom 12.1 purely in terms of moral behaviour.

111 For an account in terms of "incorporation" into the messiah, cf. Wright 2013, 825-835. 


\subsubsection{Two remarks on our solution}

Having stated this, we need to make two points of clarification. First: Our "translation" aims at showing something about the ancient cultural encyclopedia

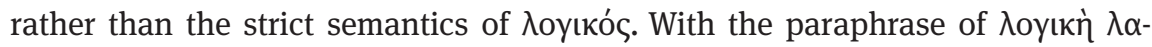

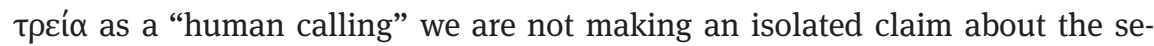

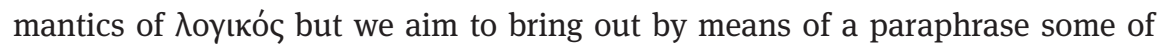
the import of the language within the ancient encyclopedia. Our gloss points

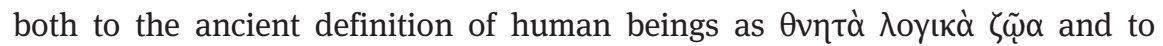
the fact that the definition is often used to speak about the human role in the cosmos. ${ }^{112}$ Because there is a strong link in the ancient encyclopedia between the endowment with reason and being human, ${ }^{113}$ a link which is no longer as prominent in modern contexts, merely translating with some word involving "reason" would fail to bring out this aspect of meaning, which is precisely the one that makes best sense of what Paul is saying overall in Rom 12.1. Thus, if some English adjective expressing something to do with reason would also show strong link to ideas about a human role in the cosmos, then such a word might help in offering a useful translation. But there is not. ${ }^{114}$ Where semantics overlaps with knowledge about the world or assumptions about it, one cannot simply translate. There needs to be awareness of the cultural encyclopedia and this might only be brought out by a paraphrase, which might look odd as a suggestion about the semantics of the word, but which is needed for understanding what is being said.

Thus, we are not wanting to say that 入оуıкó semantically says nothing more than "human" in this context. There is always a reference to $\lambda$ óyos implicit in the use of the word. ${ }^{115}$ But that reference might be secondary in terms of the mean-

112 As we have shown with regards to Epictetus 2.9 in section 4.2.

113 As we have seen in sections 2.2 and 3.1.

114 There is the additional fact that such an English adjective would also have to fit in the way it modifies the noun. Perhaps rendering "reason-endowed" might work to highlight the definition of human beings as animals endowed with reason. But it would only ever be applied to persons and not to actions and thus "reason-endowed service-to-God" would be strange.

115 Thus, there is some truth in Scott's claim that “خoyıкós never merely means 'human'. To

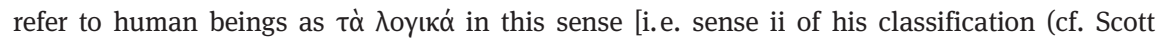
2018, 504), SD] is to highlight humanity's capacity for reasoned thought as our defining attrib-

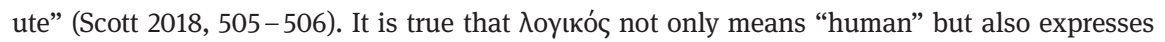
the idea that reason is constitutive for the kind of beings that we are. But often it does so, as we have shown, precisely in discourse about the purpose of human beings and what they should aim to do. They are often defined in such a way in arguments about what their goal should be. The characteristic tasks they are meant to fulfil will perforce be such that without human 
ing of $\lambda$ оуıкทे $\lambda \alpha \tau \rho \varepsilon i ́ \alpha$. Scott wants to make the semantics the primary thing in getting at the meaning of $\lambda$ оуıк่ $\lambda \alpha \tau \rho \varepsilon i ́ \alpha$, when he claims that Paul is thereby urging that the "believer's ethical sacrifice" (as he calls it) should be understood to be one which involves acts of reasoning. His reading seems to presuppose that an adjective modifying a noun expressing an action could only ever characterise the action itself. This overlooks the fact that there is an important reciprocity between characterisations of actions and characterisations of their agents. Divine providence, for example, is both a providence of a higher quality than human providence and a providence whose subjects are divine. An action which is char-

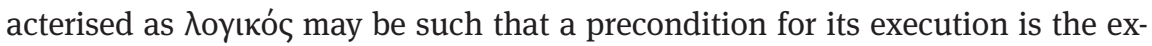
ercise of reason or even the capacity rightly to use it. Yet it may also be an action

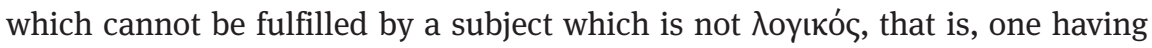
the capacity for reason and thus in principle the capacity for using reason well. The attribution of the quality to the action is implicit. But in the case at the hand it is the subject of the action that is the crucial factor.

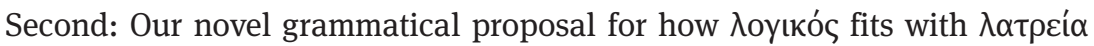
has the advantage of being able to vindicate in some measure the interpretation

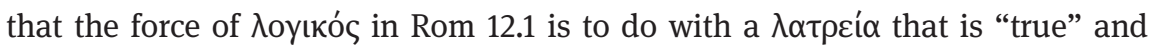
"appropriate", and hence that Paul's use of reason language contributes an evaluative effect to the statement of Rom 12.1, even if, as Scott has rightly argued, the word itself is not used to make a third-person judgment on how "reasonable" an action is. ${ }^{116}$ This is because the idea of a function of a being which depends on its specific capacity inherently elides the distinction between mere description and prescription, or fact and value. Thus, the understanding of "true worship" or "true service", or better, "appropriate service" is in some measure warranted; namely, because it is a service which is appropriate for the kind of being that a human being is. ${ }^{117}$ Those interpretations which emphasise this aspect have thus detected a nuance that really is there and should not be neglected. ${ }^{118}$

thinking of some kind they would be impossible to achieve. However, speaking about "our defining attribute" is not undertaken merely out of an interest in classifications, as Scott's account seems to suggest. Rather, the point is the vocation of human beings in the cosmos.

116 Scott 2018, 517-518. Thus, though Scott does not make his point in this manner, 入oyıkó is

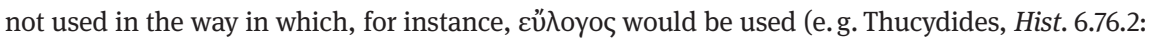

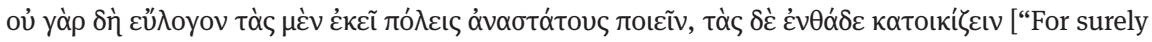
it is not reasonable to suppose that, while desolating the cities in their own country, they are resettling the cities of Sicily" (transl. C. F. Smith)]).

117 This normative aspect is completely missed by Scott. It must be added, contra Wolter's interpretation, that Paul is not saying that the form which worship has to take must be appropriate to the nature of God, humans, or both. Rather, his claim is that it is the appropriate vocation based on their nature (or restored "nature"). 


\subsection{Rom 12.2 in relation to Rom 12.1}

Having explained our reading of Rom 12.1, our goal in this section is to show briefly how Rom 12.2 coheres with and supports our interpretation of Rom 12.1. For ease of reference, we quote the text again:

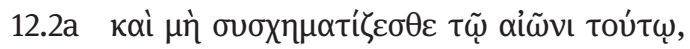

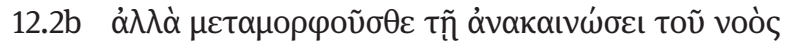

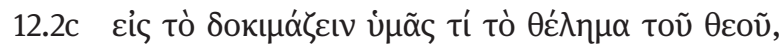

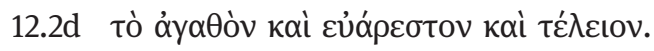

Our main point is that the exhortations in Rom 12.2a and 12.2b continue the line of exhortation in Rom 12.1b. Like Rom 12.1b, which we have shown to be about sign production, so also Rom 12.1a and 12.2b exhort to elements necessary for sign production. Romans $12.2 \mathrm{c}$ is presented as consequence of Rom 12.2b.

In Rom $12.2 \mathrm{a}-\mathrm{b}$ there is a syntactical change from an infinitive dependent upon $\pi \alpha \rho \alpha \kappa \alpha \lambda \tilde{\omega}$ (as in Rom 12.1b) to imperatives. These imperatives, however, function as exhortations as well. The first one states what Paul's hearers should not do, namely act in such a way that their behaviour conformed to that of o

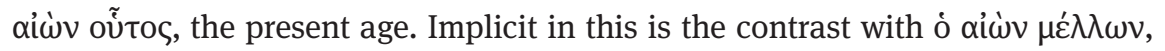
the age to come. ${ }^{119}$ Paul's use of $\sigma v \sigma \chi \eta \mu \alpha \tau i \zeta \zeta \varepsilon \sigma \theta \alpha$, to form or pattern oneself after something, ${ }^{120}$ here applied to "this age" corresponds well with our notion of a sign production of new creation: instead of displaying in their conduct the signs of this age and of the old humanity, Paul wants his hearers to produce signs of the new creation inaugurated in the messiah (though only the negative side is expressed: do not participate in the sign production of this age). ${ }^{121}$

The second imperative (Rom 12.2b) states something that Paul's hearers should do. Its content is a transformation through the renewal of the mind.

118 However, the thrust is not the implication that other forms are "false". Romans 12.1c is encouraging, protreptically, to the human calling, not commenting, first and foremost, on what others are doing (which comes into view only in Rom 12.2a).

119 Cf. on the present age and the age to come the references collected by Keener 2016, $153 \mathrm{n}$. 90.

$120 \sigma v \sigma \chi \eta \mu \alpha \tau i \zeta \varepsilon \sigma \theta \varepsilon$ is a middle-passive form, but its meaning is not passive.

121 In this interpretation, what Paul says here is very similar to what has been said in Rom 6 (for instance, in Rom 6.12). Keener similarly detects resonances with "new creation" here, when he writes with reference to Rom 12.2 that "Paul may evoke the new creation in Christ ..., which in the present includes a new worldview or approach to current reality” (Keener 2016, 154); though he rather underplays his hand when goes on to explain that this means "present actions and inactions must be evaluated in the light of their eternal consequences." 
The form $\mu \varepsilon \tau \alpha \mu о \rho \varphi о \tilde{\sigma} \theta \varepsilon$ is middle-passive, but that does not imply that the meaning expressed is passive. The parallelism with $\sigma v \sigma \chi \eta \mu \alpha \tau i \zeta \varepsilon \sigma \theta \varepsilon$ suggests that the meaning is not passive, but rather direct-reflexive. ${ }^{122}$ Thus one might translate this as "transform yourselves through the renewal of your mind." This renewal has become possible through the change of conditions brought about in the Christ event (cf. Rom 6.1-11), and by the work of the Spirit (cf. Rom 8.5-6). It corresponds to a reversal of the process of corruption described in Rom 1.28. It is likely that Rom 6.11 describes the kind of process to which Paul alludes here: by thinking through their own identity in the light of Christ's death and resurrection, they transform their thinking, and thus appropriate the new understanding of God that has become available.

This renewed understanding is then the basis for the restoration of the ap-

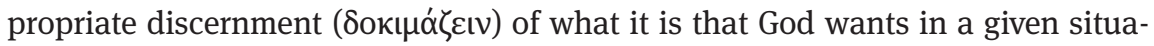
tion (Rom 12.2c). ${ }^{123}$ These right actions are described in Rom $12.2 \mathrm{~d}$ as good and

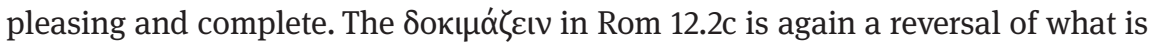
described in Rom 1.28. That the object of discernment is "what it is God wants" ( divine intentionality is one of the criteria, as we have seen in section 3.2). Based

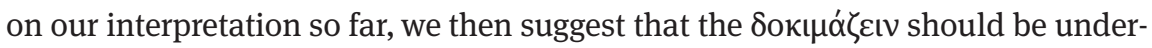
stood as vocational discernment. It is the determination, in a given situation of how best to produce the signs in which the vocation consists (Rom 12.1b). That is, the discernment is about how a particular action would produce a sign of the good news and of the new creation inaugurated in the messiah.

Our reading of Rom $12.12 \mathrm{~b}$ and $12.2 \mathrm{c}$ then suggests the following explanation of how the renewal of the mind relates to the vocational discernment. The structure of the human vocation is a sign production based on an understanding of God in relation to the world. The renewal of the mind refers to a process of deeper appropriation of the new understanding of God that has become available, of the new creation launched in the messiah's death and resurrection. The discernment is then about how to produce, in a given situation, the appropriate sign of new creation based upon this understanding.

122 On direct-reflexive meaning cf. CGCG, 35.11.

123 On discernment see Munzinger 2007 (with a focus on the Spirit). 


\subsection{Conclusion}

We have thus shown in exegetical detail how our proposed explanation of Paul's reason language in Rom 12.1 works. By alluding to philosophical traditions about

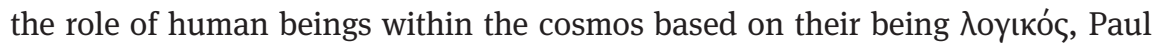
presents the missional sign production of those in Christ as their truly human vocation. We have shown in detail how Epictetus functions as a parallel in terms of the idea of a human vocation. We have made this sense plausible in Rom 12.1 by a new grammatical consideration of how the adjective $\lambda$ oyıkó fies the action noun $\lambda \alpha \tau \rho \varepsilon i ́ \alpha$. We have further shown how Rom 12.1-2 coheres with this interpretation.

By arguing that Paul shares with the philosophers the idea about human beings as those endowed with reason and with a role in the cosmos based on this endowment, we have emphasised continuity with the philosophical tradition. However, as we have already seen in section 5.3, and will see in the next chapter, Paul's use of this idea goes significantly beyond the philosophical tradition in its eschatological and christological orientation. Paul sees the service which is appropriate to human beings as that of a missional existence - of understanding who God is and of producing appropriate signs. ${ }^{124}$ In the next chapter we will show the implications our reading for how Rom 12.1-2 frames Rom 12-15.

\footnotetext{
124 In using the language of "service", we may seem to focus more on one side of what should be considered to be a double movement - from God through humans to the world ("mission") and from world through humans to God ("worship"). This double aspect is brought out well in Wright's statement that humans as God's image-bearers are called to be "summing up the worship of creation and reflecting his wise order into his world” (Wright 2013, 1509). Our emphasis on service as a human vocation is based on reading Paul in Rom 12.1 in the light of Epictetus 1.16 and 1.6. But since we use "service" comprehensively, it should be clear that both aspects are included. For our use of "mission" and "missional”, see section 1.4.
} 